\title{
EFFECTS OF VARIABLE TIRE PRESSURE ON ROAD SURFACINGS
}

\author{
by \\ Robert W. Grau \\ Geotechnical Laboratory \\ DEPARTMENT OF THE ARMY \\ Waterways Experiment Station, Corps of Engineers \\ 3909 Halls Ferry Road, Vicksburg, Mississippi 39180-6199

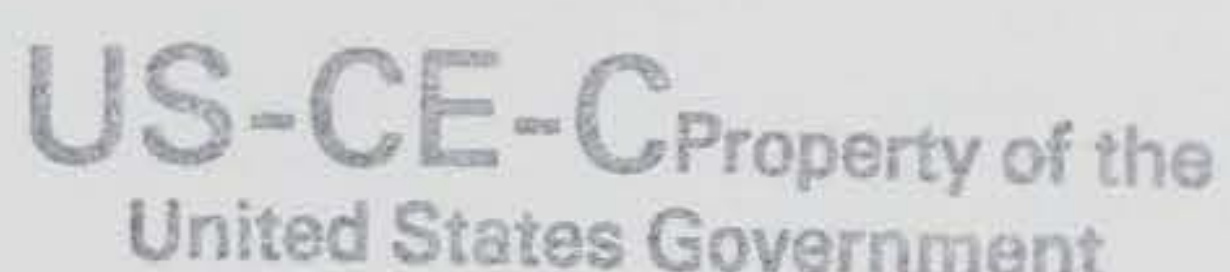

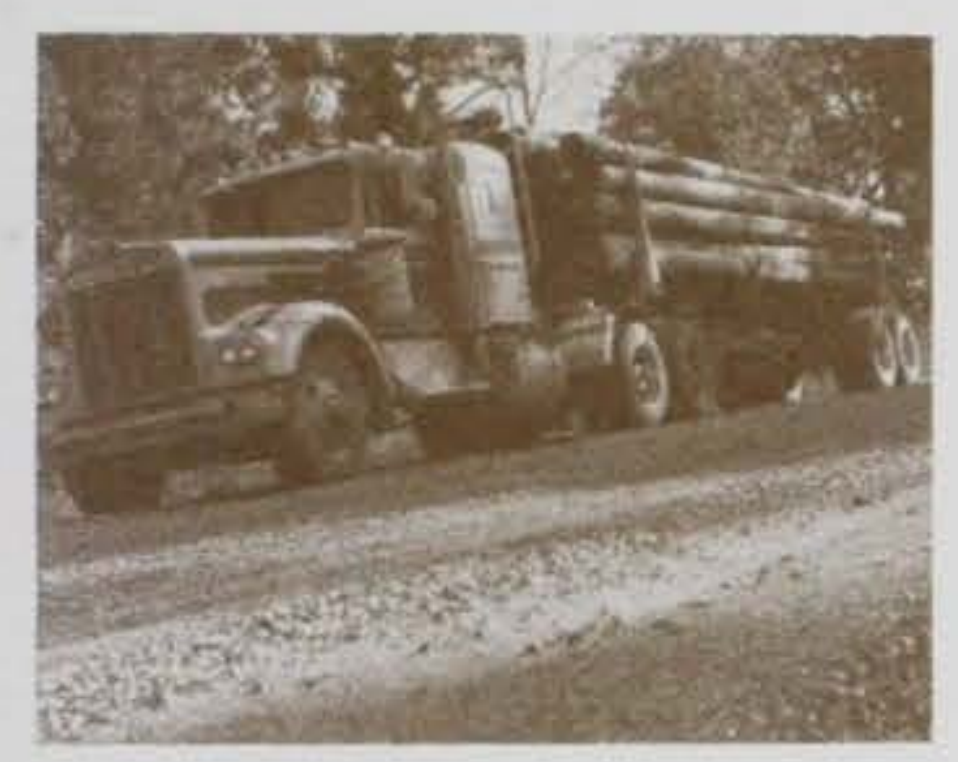
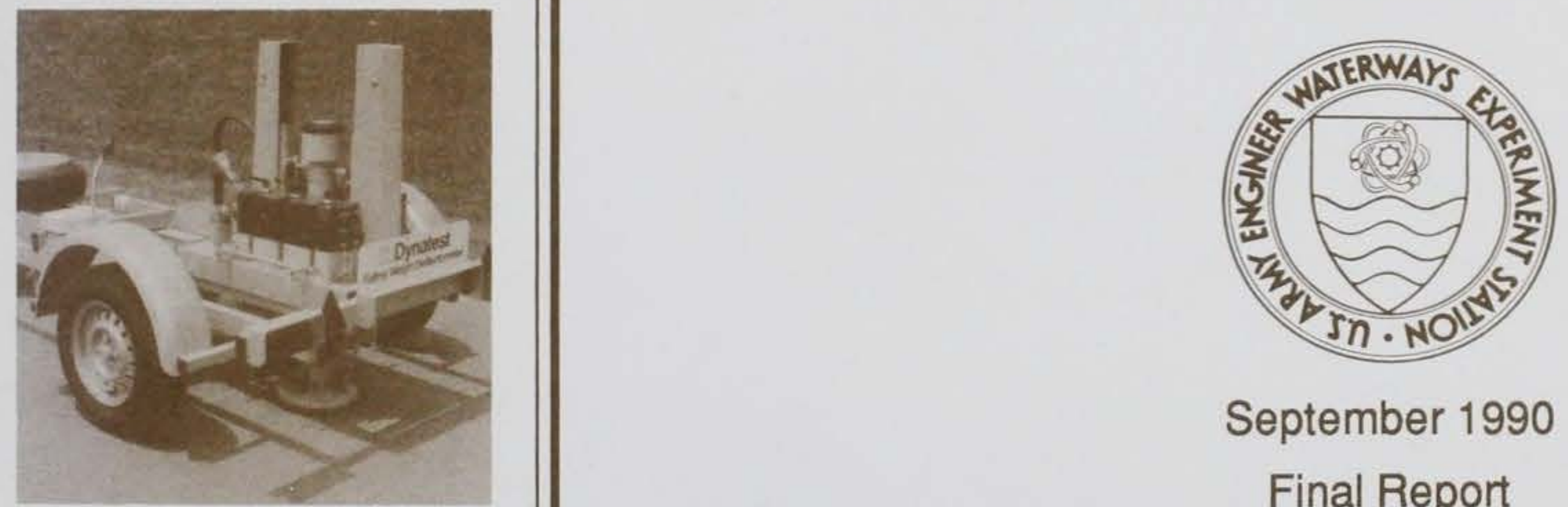

September 1990

Final Report

Approved for Public Release; Distribution Unlimited

RESEARCH LIERARY

US ARMY ENGINEER WATERWAYS

EXPERIMENT STATION

VICKSBURG, MISSISSIPPI

Prepared for DEPARTMENT OF AGRICULTURE Forest Service Technology and Development Center 444 East Bonita Avenue, San Dimas, California 91773 


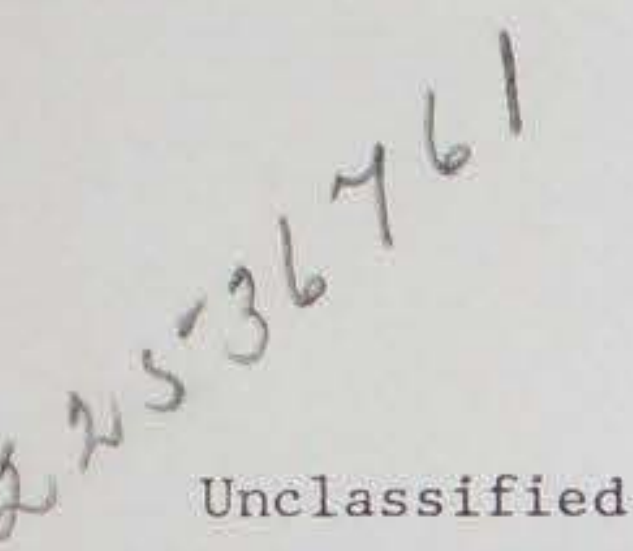

SECURITY CLASSIFICATION OF THIS PAGE

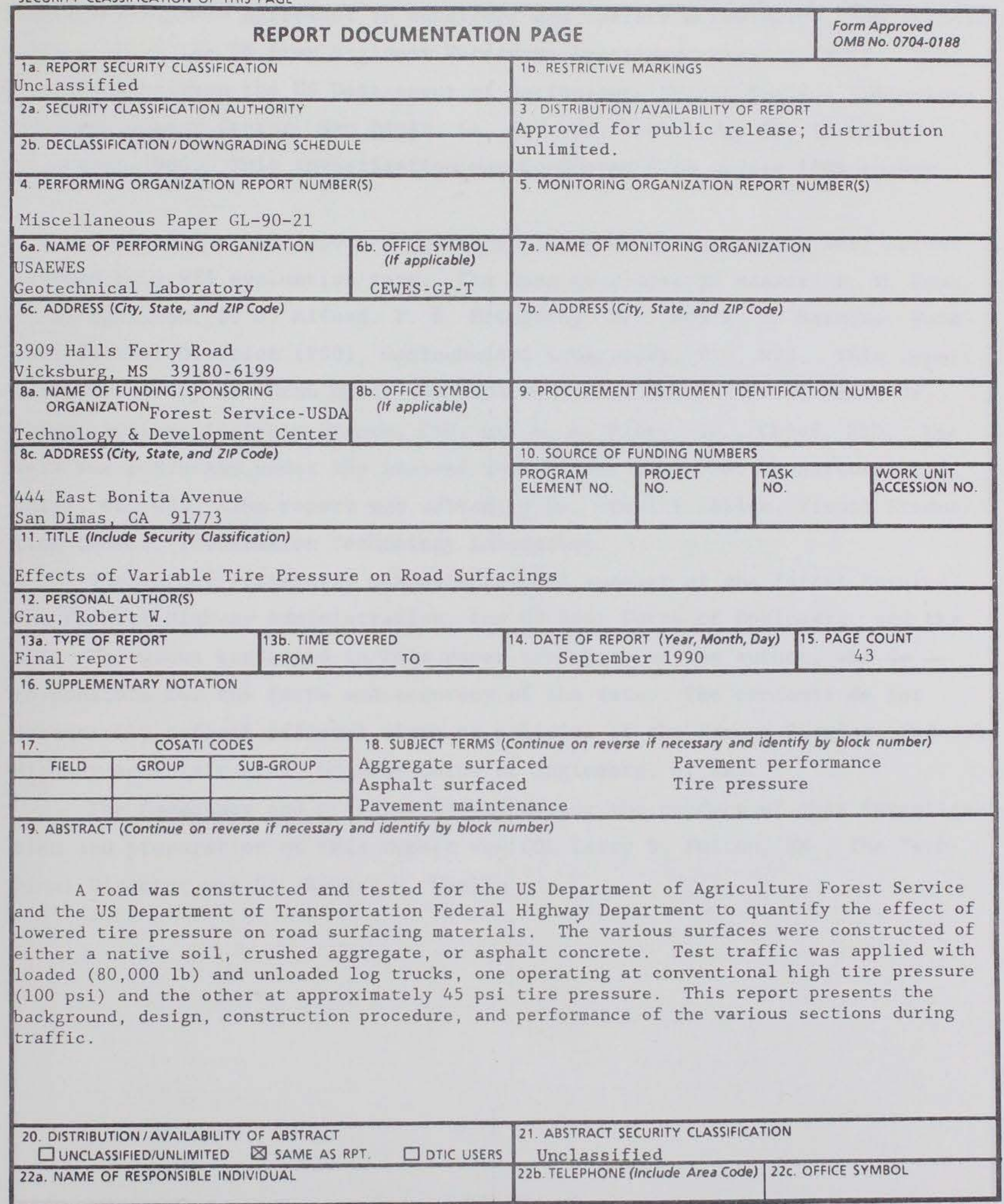


The authority for performance of this investigation is contained in a Technical Support Agreement to construct and operate a low-speed, low-standard test road at the US Army Engineer Waterways Experiment Station (WES). This agreement between the US Department of Agriculture Forest Service Technology and Development Center, San Dimas, CA, and WES, Vicksburg, MS, is dated 22 August 1986. This investigation was conducted from August 1986 to May 1990.

The testing and report preparation for this investigation were accomplished by a WES evaluation team. The team consisted of Messrs. R. W. Grau, J. A. Harrison, S. J. Alford, P. S. McCaffrey, Jr., and D. D. Mathews, Pavement Systems Division (PSD), Geotechnical Laboratory (GL), WES. This report was prepared by Mr. Grau under the supervision of Messrs. J. W. Hall, Jr., Chief, Systems Analysis Branch, PSD, and H. H. Ulery, Jr., Chief, PSD. The work was performed under the general supervision of Dr. W. F. Marcuson III, Chief, GL, WES. The report was edited by Ms. Odell F. Allen, Visual Production Center, Information Technology Laboratory.

The author gratefully acknowledges the support of the Forest Service, the Federal Highway Administration, the US Army Corps of Engineers, and the WES. The views expressed in this paper are those of the author, who is responsible for the facts and accuracy of the data. The contents do not necessarily reflect official views or policies of the Forest Service, Federal Highway Administration, US Army Corps of Engineers, or WES.

The Commander and Director of WES during the conduct of this investigation and preparation of this report was COL Larry B. Fulton, EN. The Technical Director was Dr. Robert W. Whalin. 
PREFACE. . . . . . . . . . . . . . . . . 1

CONVERSION FACTORS, NON-SI TO SI (METRIC)

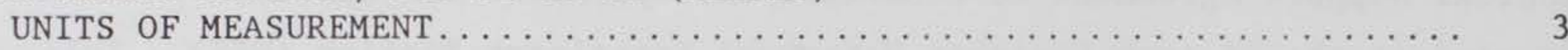

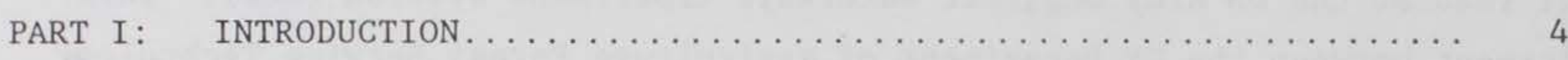

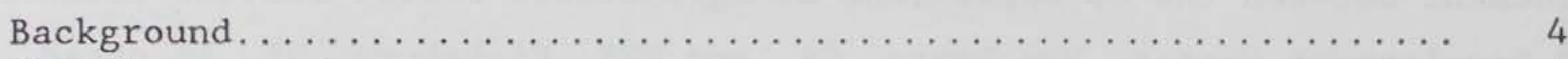

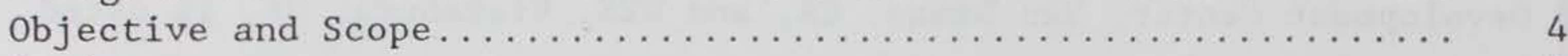

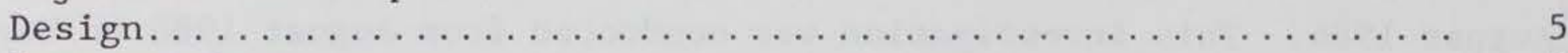

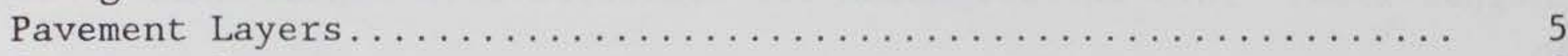

Construction. . . . . . . . . 6

PART II: TESTING AND BEHAVIOR UNDER TRAFFIC $\ldots \ldots \ldots \ldots \ldots \ldots \ldots \ldots \ldots$

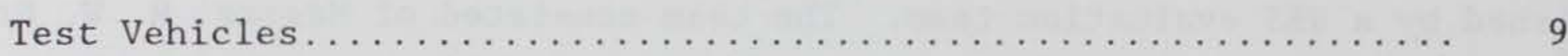

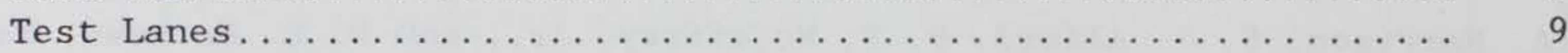

Failure Criteria............................... 10

PART III: BEHAVIOR OF PAVEMENT UNDER TRAFFIC $\ldots \ldots \ldots \ldots \ldots \ldots \ldots \ldots \ldots \ldots$

General. . . . . . . . . . . . . . . . . . 12

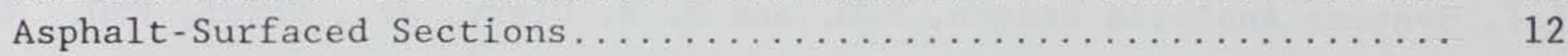

Aggregate-Surfaced and Native Section................. 14

PART IV: SUMMARY OF FINDINGS AND RECOMMENDATIONS $\ldots \ldots \ldots \ldots \ldots \ldots \ldots \ldots$

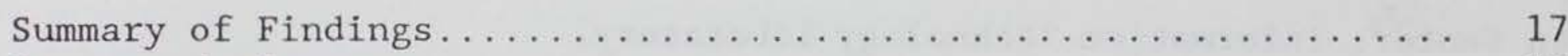

Recommendations......................... 17

TABLES $1-5$

FIGURES $1-25$ 


\section{CONVERSION FACTORS, NON-SI TO SI (METRIC) \\ UNITS OF MEASUREMENT}

Non-SI units of measurement used in this report can be converted to SI (metric) units as follows:

Multiply
feet
gallons per square yard
inches
miles (US statute)
pounds (force)
pounds (force) per square
inch
pounds (mass) per cubic
foot

$\frac{\text { By }}{0.3048}$
4.5273
2.54
1.609347
4.448222
6.894757
16.01846

To Obtain
metres
cubic decimetres per
square metre
centimetres
kilometres
newtons
kilopascals
kilograms per cubic
metre




\section{EFFECTS OF VARIABLE TIRE PRESSURE ON ROAD SURFACINGS}

PART I: INTRODUCTION

\section{Background}

1. The US Department of Agriculture Forest Service is responsible for approximately 340,000 miles* of roads in the national forests. Seventy-five percent of these roads are low-volume, one-lane, gravel-surfaced roads. In 1983 the Forest Service Technology and Development Center, San Dimas, CA, began to study the effects of variable tire pressure on the cost of transporting forest products and how central tire inflation (CTI) systems that allow a driver to adjust a vehicle's tire pressure while in motion will be cost effective. A portion of this study was structured tests conducted on test courses where variables such as pavement surfacings, thicknesses, grades, curvatures, and surface distresses could be controlled and quantification of the effect of lowered tire pressure be documented. Structured tests were conducted at the Nevada Automotive Test Center to quantify the effect of lower tire pressure on tire and truck performance and at the US Army Engineer Waterways Experiment Station (WES) to quantify the effect of lower tire pressure on road surface deterioration and pavement thickness requirements. It is hoped that the results from this study will show tremendous benefits of CTI and thus encourage the development and use of CTI equipment in the logging industry. This, in turn, will result in increased income from timber sales for the Forest Service Regions by reducing the effort required to maintain the roads during timber hauling. Considerable savings should be realized in the construction and maintenance of roads by the reduction of truck and tire wear and from the extension of haul seasons.

\section{Objective}

2. The objective of this investigation was accomplished by the construction and traffic testing of a specially designed test road. The test

* A table of factors for converting non-SI units of measurement to SI (metric) units is presented on page 3. 
road was subjected to both loaded and unloaded 18-wheeled 1 g trucks operating in two distinct traffic lanes. This paper describes the background, design, construction procedure, test procedures, and performance of the various test sections during traffic.

\section{Design}

3. The test road was designed to determine the effect of tire pressure (deflection) on road surface deterioration and thickness design of low-volume roads. This road was approximately $0.7 \mathrm{mile}$ in circumference with parallel 12-ft-wide traffic lanes. It was divided into 15 sections including curves and grades. The surfaces of these sections were constructed of either native soil crushed aggregate or asphalt concrete (AC). The total pavement thickness or layer thicknesses were varied for each of the 15 sections in order that failures or different amounts of distress would occur throughout the proposed traffic period. A plan view of this road is shown in Figure 1 . The type and thickness of the various pavement or surfacing layers for each section are also indicated in Figure 1. The proposed traffic consisted of 3,000 loaded $(80,000 \mathrm{lb})$ and unloaded passes of an 18 -wheeled log truck on all sections and 18,000 additional loaded passes on the AC sections.

\section{$\underline{\text { Pavement Layers }}$}

4. The natural soil at the test site was utilized as subgrade material for all sections and for surfacing of section 3 . The soil has a liquid limit of 32 and a plasticity index of 12 and classifies as a lean clay (CL) according to the Unified Soil Classification System*. Classification data are shown by curve 1 in Figure 2 .

5. A 4- to 8-in.-thick crushed aggregate base course was specified for six of the nine AC-surfaced test sections. Five sections were surfaced with 3- to 9-in. layers of this same crushed aggregate. The material used (crushed

* Department of Defense. 1968. "Military Standard of Unified Soil Classification System for Roads, Airfields, Embankments, and Foundations," MIL-STD-619B, Washington, DC. 
limestone) met all requirements set forth in EM 7720-100R* for base or surface courses, grading D. A grading curve for this material is shown as curve 2 in Figure 2.

6. A mix design for the AC surfacing layer placed on nine of the test sections was in accordance with that required by the Louisiana Department of Transportation and Development**. The combined grading curve for the AC mixture and the gradation specification limits are shown in Figure 3 . The design asphalt content for this mixture was 4.6 percent.

\section{Construction}

7. The test road was constructed from September 1986 to September 1988. All work was accomplished under contract by Lewis Miller Construction Company, Inc., Vicksburg, MS. The contract was issued by the US Department of Agriculture Forest Service Kisatchie National Forest (KNF). WES and KNF provided inspectors during construction of the test road.

8. Prior to subgrade construction, trees were removed and vegetation stripped from a 100 - to $150-\mathrm{ft}$-wide path along the center line of the test road. Subgrade construction consisted of rough grading and placement and compaction of fill material to at least 90 percent of AASHTO T $180 \dagger$ to an elevation of $1 \mathrm{ft}$ below finished subgrade along the entire roadway. Barrow material was then brought in, and the entire roadbed was elevated to $1 \mathrm{ft}$. The barrow and existing subgrade material were the lean clay described above The barrow material was hauled and spread with self-loading scrapers into an 8- to 10-in. loose lift. The desired density, 95 percent of AASHTO T 180, was achieved by compacting with a sheepsfoot and self-propelled, rubber-tired roller. Water content and density tests were performed on each lift of all sections to verify that the desired density had been obtained. After the

* US Department of Agriculture. 1985. EM 7720-100R, "Forest Service Specification for Construction of Roads and Minor Drainage Structures," Washington, DC.

** Louisiana Department of Transportation and Development. 1982.

"Louisiana Standard Specifications for Roads and Bridges," Baton Rouge, LA.

† American Association of State Highway Officials. 1961. "Standard Specifications for Highway Materials and Methods of Sampling and Testing," Washington, DC. 
final lift had been compacted and met density requirements, it was fine bladed to the desired elevation and sealed with the rubber-tired roller.

9. The base material for the AC-surfaced sections and aggregate surfacing material is the crushed limestone described under pavement layers. The material was saturated in the stockpile prior to loading on dump trucks for transport to the test road. The material was placed in one to three lifts of approximately $3 \mathrm{in}$. each by use of an asphalt finisher to prevent segregation. The single-drum vibratory roller, shown in Figure 4, was utilized to compact this material. Compaction was continued on each lift until maximum density was achieved. A nuclear moisture density meter was used to measure the density during compaction. Generally, the desired density, 95 percent of AASHTO $\mathrm{T}$ 180, was not obtained. This is attributed to the fact that the highquality crushed limestone material was, in some cases, relatively thin and, in all cases, being placed directly on a relatively weak subgrade with no in between intermediate strength subbase material. After compaction, the sections to be surfaced with AC were primed with approximately $0.30 \mathrm{gal} / \mathrm{sq} \mathrm{yd}$ of MC-70 cutback asphalt.

10. The $A C$ hot mix was placed with an asphalt finisher (Figure 5) in two 12 -ft-wide lanes and one 10-ft-wide lane. The 2-in. pavement was placed in one lift, and the 4- and 5-in.-thick pavements were placed in two layers. The 6 -in. pavement in section 11 was placed in three 2 -in.-thick layers . Compaction of each layer was obtained by breakdown rolling with a tandem steel-wheeled roller (Figure 6), followed by a self-propelled, rubber-tired roller (Figure 7). Prior to laydown, samples were obtained from the mix for laboratory extraction, gradation, and compaction tests to ensure uniformity and compliance with the job-mix design. The properties of the mix were within the job-mix limits except the percent total voids which averaged 2.8. Three percent was the lower limit of the voids total mix. After compaction, cores were cut and tested for density. Results of these tests indicate that the percent density of the in-place mix to the remolded specimens was 97.5 which is slightly less than the 98 percent required.

11. A summary of the as-constructed ( 0 pass data) thickness, California Bearing Ratio (CBR), water content, and density of the various pavement layers in each test section is given in Table 1 . The field data measurements were obtained from test pits excavated from the surface of the pavement to 6 in. below the surface of the subgrade. The test pits were located in a nontraffic 
area along the center line of the roadway at about the midpoint of each test section. The relatively low CBR values (21-47) indicated for the crushed stone base and surfacing material were due to the thin (3- to 7.5-in.) layers of this material being placed over the subgrade which had CBR values ranging between 7 and 22. Pumping was observed during compaction of the crushed aggregate material which indicates deflection and yielding of the subgrade under the roller, causing the inability to obtain the desired density and resulting strength. 


\section{Test Vehicles}

12. Traffic tests were performed on two separate lanes of the test road. The test vehicles, test lanes, traffic patterns, failure criteria, and performance of the various pavement sections during traffic are discussed in the following paragraphs.

13. Traffic was applied to the test road with the two 18 -wheeled $10 \mathrm{~g}$ trucks, shown in Figure 8, running in separate test lanes (low and high pressure) around the test track. Test traffic included both loaded and unloaded passes of the log trucks. Table 2 shows the weights of each side of the five axles under each loaded truck and the total gross weight per truck. Al1 wheels on the trucks were equipped with 11R24.5 XZY, load rating G, 14-ply tires. One truck was operated at typical highway pressure of 100 psi in all tires which resulted in tire deflections of about 10 and 7 percent when loaded and unloaded, respectively. The low-tire-pressure truck operated at a constant tire deflection (21 percent) which required tire pressures of approximately 30 and 25 psi for the loaded and unloaded conditions, respectively.

\section{Test Lanes}

14. The test road was divided into two lanes (high and low tire pressure) and two loops (the entire test road and the AC sections only). The high-tire-pressure truck operated in the outside lane at all times, and the low-tire-pressure truck operated in the inside lane. The loaded traffic was run in a counterclockwise direction while unloaded traffic ran in the clockwise direction. This traffic pattern resulted in simulating actual forest harvest conditions in that the loaded trucks are traveling down an aggregate grade and the unloaded trucks up the grade. During the trafficking of the aggregate sections, loaded and unloaded traffic was alternated on a daily basis until significant data were obtained to determine the difference in performance. Load traffic was then applied full-time. When measurements or repair was required on the aggregate portion of the test road, the asphalt cutoff was utilized and only the AC portion or sections 4 to 12 trafficked. A summary of the total traffic applied is shown in Table 3. 


\section{Failure Criteria}

15. In judging failure of the AC test sections, the performance of the surface course and underlying layers were considered. Base course and subgrade failures due to shear deformation were anticipated because it was not possible to apply a heavy compaction effort in the thinner pavement sections. The term shear deformation as used herein refers to excessive plastic movement or, in the extreme, the rupture of any element in the pavement structure. This was evident when severe rutting and longitudinal cracking of the surface course was observed. Rut depths are defined as the maximum vertical distance from the bottom edge of a straightedge placed on the shoulders (upheaval) of the rut to the bottom of the rut. Shoving was also a major type of distress observed during the trafficking of the test section. Shoving occurred in the outside wheelpath of a horizontal curve and could be detected by either the outward movement of the total thickness of AC or of the top layer in relation to the underlying layer.

16. Since hot bituminous mixes are placed to provide a smooth riding surface and waterproof the base against the penetration of surface water, a pavement section was considered failed when either of the following conditions occurred:

a. Surface rutting of $2 \mathrm{in.}$ or more along a continuous 20 -ft-long rut.

b. Surface cracking to the extent that the pavement was no longer waterproof.

c. Severe shoving which resulted in 2 -in.-deep ruts or severe cracking of the AC surface.

17. Aggregate is placed on a gravel-surfaced road to protect the subgrade from being overloaded and to make the surface more resistant to the abrasive effects of traffic. The ability of the aggregate layer to carry heavy sustained traffic mainly depends upon the thickness of the layer. Reduction in thickness such as rutting decreases the load-carrying capacity of an aggregate-surfaced road. Gravel roads require considerable maintenance such as blading and dust control to correct rutting and washboarding. Ruts are defined and measured for gravel roads, as described above, for AC-surfaced roads. Washboarding is a series of closely spaced ridges and valleys perpendicular to the direction of traffic and at fairly regular intervals. Washboarding is measured in inches and is the vertical distance between the top of 
the ridge and bottom of the valley. The aggregate sections were considered failed when any of the following conditions existed in a 20-ft-long section of a wheelpath:

a. Three-inch ruts in test sections 1,2 , and 13 .

b. Four-inch ruts in test sections 14 and 15 .

c. Washboarding of 3 in. or more.

The 3-in. rut depth failure criteria were used for sections 1,2 , and 13 because the total thickness of the aggregate layer was only 3 in. A greater degree of rutting in these sections would result in the bottom of the rut possibly being below the aggregate/subgrade interface. Grading would then result in a soil aggregate layer rather than an aggregate surface. After several grading cycles, the original aggregate would be of little benefit structurally or as a surfacing material because of contamination. 


\section{General}

18. Visual observations of the behavior of the test sections were recorded throughout the traffic test period of each lane. These observations were supplemented by photographs. Level readings, nondestructive testing utilizing a falling weight deflectometer, condition surveys, roughness measurements, asphalt strain, deflections at various depths in selected AC sections, drop cone penetrometer readings, pavement temperature, and various climatic data obtained from an onsite weather station were recorded prior to and at intervals during traffic to show the development of pavement distress. After failure, a thorough investigation was made by excavating test trenches across the wheelpaths to observe the various layers in the structure along with CBR measurements and other pertinent tests in these layers. General observations, rut measurements for all sections, and maintenance frequencies for the aggregate sections taken during traffic are discussed in the following paragraphs. Tables 4 and 5 give a summary of the maximum rut depths and general remarks for the failures occurring in the AC unsurfaced sections, respectively. An in-depth analysis of the measurements and data recorded during the conduct of this investigation are not complete at this time.

\section{Asphalt-Surfaced Sections}

19. At the beginning of traffic, slight pumping of the surface was observed as the high-tire-pressure truck traversed the 2-in.-thick AC sections. Surface deformation and pumping was most evident in the outside wheelpaths of the horizontal curves. After about 71 passes, distinct rutting and hairline longitudinal cracking along the outside edges of wheelpath 2 were noticed in section 4. As traffic continued, the rutting and cracking in section 4 became more severe; one area was rated as failed after 158 passes. Figure 9 depicts a general view of this initial failure in the AC portion of the rest road. The maximum rutting in this area was $2.3 \mathrm{in}$. deep, and the cracking had progressed into alligator cracking. After an additional 165 passes, for a total of 323 passes, a second failure occurred in section 4, wheelpath 2. Figure 10 shows a general view of this second failure. It 
should be noted that again the majority of the rutting occurred in wheelpath 2 , and very little distress had occurred in wheelpath 1 . Wheelpath 1 in section 4 is located in the inside portion of the curve. This failure is attributed to overloading or failure of the subgrade. Figure 11, which is a view of a test pit excavated in the failed area, indicates severe rutting of the subgrade. At the time of this second failure in the high-tire-pressure lane (323 passes), very little distress was present in the low-tire-pressure lane. There was no cracking evident, and the maximum rut depth was only $0.5 \mathrm{in.}$ The rate of pavement deterioration with traffic decreased after the second failure. The next failures occurred after 1,104 and 1,414 passes in wheelpath 1 of sections 6 and 5, respectively. When these sections were judged failed in the high-tire-pressure lane, only hairline cracking and minor rutting were detected in the low-tire-pressure lane. The average rut depth in the low-tire-pressure lane of section 6 after 1,104 passes was about 0.7 in. and in section 5 about $0.4 \mathrm{in}$. after 1,414 passes. Throughout the remainder of traffic in the high-tire-pressure lane $(6,764$ loaded passes), only two additional failures occurred, one in section 5, wheelpath 1 after 2,210 passes and another in section 10, wheelpath 1 at 2,210 passes also. The mode of failure in section 5 was the same as the previous failures, and the section 10 failure was attributed to severe shoving of the top lift of AC after 1,812 passes (see Figure 12) and then severe cracking and rutting of the surface as shown in Figure 13. The failure in section 10 occurred in an area where the traffic was entering a horizontal curve and at the beginning of warm weather traffic. Test traffic was applied to the AC section during two periods, from October 1988 to February 1989 and from June to November 1989. The shoving, shown in Figure 12, occurred after 245 passes had been applied in June 1989. Shoving (Figure 14) was detected in the low-tire-pressure lane of section 10 after 1,200 passes of warm weather traffic or a total of 4,200 passes.

20. Four failures, two in section 4 and one each in sections 5 and 6 , occurred in the low-tire pressure lane. The failures in sections 5 and 6 were judged as failed after 2,076 passes and those in section 4 after 3,324 and 3,845 passes. Severe cracking and rutting were the mode of each of these failures. A general view of the portion of section 5 was failed after 2,076 passes as shown in Figure 15 . 
21. Although the same criteria were used in judging failure in both traffic lanes, the rutting at failure in the high-tire-pressure lane appeared more pronounced. Generally, there was very little upheaval associated with the ruts in the low-tire-pressure lane. Also, the ruts caused by the lowtire-pressure truck were 6 to $12 \mathrm{in}$. wider than those in the opposite lane.

\section{Aggregate-Surfaced and Native Section}

22. At the beginning of traffic, it was evident that sections 1 to 3 would withstand very few passes of the 80,000-1b log trucks. Rutting was observed in both lanes of these three test sections after one pass. After 58 passes in the high-tire-pressure lane and 66 passes in the low-tirepressure lane, traffic was discontinued because of 2 -in.-deep or greater ruts in the wheelpaths of these three sections. Figures 16 and 17 show views of the low- and high-tire-pressure lanes of section 1 at failure. The only noticeable difference in the performance of the two lanes in sections 13 to 15 at this time was low-severity washboarding in the high-tire-pressure lane of section 15 (see Figure 18) as compared to none in the other sections. It was determined that because of the weak subgrade beneath sections 1 to 3 , very little additional information could be gained by blading and applying more test traffic. Therefore, they were overlaid with enough aggregate (12-in. thick layer) to bridge the weak subgrade and withstand the scheduled test traffic. During the remainder of traffic, these sections were monitored to determine the effect of tire pressure on maintenance requirements. As traffic was continued, loaded and unloaded traffic was alternated on a daily basis. Very little distress was noticed during the first day of traffic, which totaled 60 and 72 passes of loaded trucks over the high-and low-tire-pressure lanes, respectively. The next day the unloaded trucks operated and washboarding were very noticeable in section 2 in the high-tire-pressure lane after about 50 passes. The corrugation was $2.5 \mathrm{in}$. deep, and the truck driver reduced the speed in order to safely maneuver over section 2. After 112 passes, severe washboarding was measured throughout the high-tire-pressure lane of section 2. At this time, this section was judged as failed and required blading. Unloaded traffic was applied directly after blading which resulted again in washboarding. After 10 passes, the high-tire-pressure truck again had to reduce speed, and after 35 passes the corrugations were 2.5 in. 
deep. When traffic was switched to loaded, the maximum depth of washboarding decreased about an inch. The high-tire-pressure unloaded traffic continued to cause severe distress in section 2, and after 584 loaded and 556 unloaded passes this section was graded for the fourth time. Performance at this section was then discontinued. Very little distress was observed in the lowtire-pressure lane of section 2, and grading was never required. The greatest distress occurred when a pothole occurred in the no-test-section area adjacent to this section which resulted in washboarding migrating into section 2 . However, as shown in Figure 19, the low-pressure tires seemed to dampen out the bouncing of the truck which resulted in no corrugation 15 to $20 \mathrm{ft}$ from the pothole. The horizontal curves in section 1 perform approximately the same under low- and high-tire-pressure traffic. Neither required grading after being overlaid. The high-pressure-tire lane received 2,586 and 1,172 passes of loaded and unloaded traffic, respectively, and the low-tire-pressure lane received a total of 3,023 loaded and 1,384 unloaded passes of the $10 \mathrm{~g}$ truck. By the end of traffic, the only distress observed was minor rutting in both lanes and low-severity corrugation in the high-tire-pressure lane. Figures 20 and 21 show general views of the high-and low-tire-pressure lane, respectively, of section 1 depicting the above distresses.

23. Due to the higher subgrade strengths and no vertical or horizontal curves, sections 13 to 15 performed much better during traffic than did sections 1 to 3 . Very little distress was detected in sections 13 to 15 until about 90 passes of loaded traffic was applied to both lanes during a light rain. This traffic caused considerable increase in rutting of all wheelpaths of each test section. Each section was rated as failed due to severe rutting. General views of the high-and low-tire-pressure lanes of section 14 at this time are shown in Figures 22 and 23. Each section was considered failed and required grading. It should be noted that these failures were attributed to a wet subgrade, and there was no notable differences between the performance of the various items or test lanes. After grading, traffic was continued using both loaded and unloaded trucks. Test traffic (loaded and unloaded) was only applied during dry conditions. Very little distress was observed with traffic being applied under these conditions; therefore, it was decided to discontinue the unloaded traffic. After several days of loaded traffic, the rut depths in all wheelpaths of section 13 to 15 averaged about $1.5 \mathrm{in}$. with little indication of increasing. An irrigation system was then installed to simulate 
rainfall and weaken the pavement structure at a controlled rate. As water was applied, drop cone penetrometer measurements were taken in order to monitor the aggregate and subgrade strengths. As traffic was applied, failure was reached once it enter into the high-tire-pressure lane of section 14 and three times in section 15 due to rutting and severe washboarding. No failures were recorded in the low-tire-pressure lane. Figure 24 shows the high-severity washboarding in the high-tire-pressure lane of section 14 at failure. For comparison purposes, a view of the maximum distress in the low-tire-pressure lane of section 14 at the same time the high-tire-pressure lane was rated failed is shown in Figure 25. 


\section{Summary of Findings}

24. The findings from the traffic testing of the CTI test road showed that:

a. The failures or distresses in the high-tire-pressure lane of the AC sections were more pronounced than those in the lowtire-pressure lane.

b. When failures occurred in both lanes of the same AC section, the ratio of low-tire-pressure to high-tire-pressure traffic to initial failure ranged between 1.5 and 21 .

c. More raveling was observed in the low-tire-pressure lane in the horizontal curves of the AC sections than in the high-tirepressure lane.

d. Comparative pavement performance of the thicker AC sections is unavailable because traffic was stopped before failures occurred.

e. The first failures which occurred in sections 1 to 3 and 13 to 15 should not be considered in the analysis of the test results. These failures occurred in both lanes after the same amount of traffic had been applied directly after a rain. All of these failures were attributed to subgrade failure.

f. Considerable maintenance will be required on aggregate-surfaced grades receiving high-tire-pressure unloaded traffic because of the severe washboarding. This type of distress is not a factor under low-tire-pressure traffic.

g. There was no appreciable difference in the performance of aggregate-surfaced horizontal curves due to the different tire pressures.

h. The performance of the straight and flat aggregate sections was considerably better in the low-tire-pressure lane as compared to the high-tire-pressure lane.

\section{Recommendations}

25. Based on the performance or lack of performance of the 15 sections under the loading conditions as reported herein, it is recommended that:

a. Additional traffic be applied. Only one failure occurred in the thicker AC sections and very little comparative data with the exception of some maintenance data were obtained during the trafficking of the aggregate sections.

b. At the minimum, the existing test results be normalized and analyzed. 
c. Consideration be given to alternating the loaded and unloaded traffic after 10 passes or whatever the normal interval is when harvesting a forest when and if additional traffic is applied. Continuous unloaded traffic of the high-tire-pressure truck was very severe on the aggregate-surfaced sections. 
Table 1

Summary of Moisture, Density, and CBR Measurements

Test

Section

1

1

3

$4 \quad \mathrm{H} \& \mathrm{~L} \quad \mathrm{AC}$

Aggregate

Subgrade

4

4

4

Subgrade

Subgrade

Subgrade

H\&L Subgrade

AC

Aggregate

Subgrade

H

$\mathrm{AC}$

Aggregate

Subgrade
L Aggregate

H Aggregate $\quad 3 \quad 4.0$

Thickness, in. Design Actual

4.8

- -

$-$

3.8

$\begin{array}{lr}\text { AC } & 2 \\ \text { Aggregate } & 4 \\ \text { Subgrade } & --\end{array}$

$\mathrm{H} \quad \mathrm{AC}$

Aggregate

Subgrade

2.5

3.8

2.0

2.0

3.5

3.5

3.0

3.5
Water Place

In-

Depth CBR Content Density

$\frac{\text { Passes }}{0} \frac{\text { in. }}{0}$

$\frac{8}{47}$

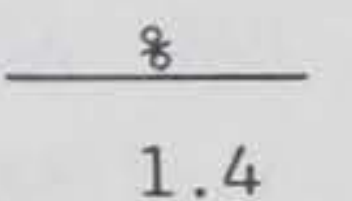

pcf

-. 0

12

128.5

06

7

18.4

102.8

$0 \quad 0$

23

$20.5 \quad 100.0$

-. 0

$1.6 \quad 124.4$

8

$18.5 \quad 105.2$

6

25

$16.5 \quad 106.5$

$\begin{array}{lll}0 & 0 & 22\end{array}$

$1.7 \quad 125.4$

. 0015

$20.1 \quad 99.5$

$\begin{array}{llll}6 & 10 & 18.5 & 103.5\end{array}$

$\begin{array}{lllll}0 & 0 & 18 & 17.3 & 103.0\end{array}$

$\begin{array}{llll}6 & 25 & 18.1 & 106.8\end{array}$

-. 0

25

131.4

3.5

-. 0

$\begin{array}{ll}7 & 106.7\end{array}$

19.2

6

13

100.2

21.4

158

-. 0

$11 \quad 136.9$

4.6

- 0

$\begin{array}{ll}6 & 105.5\end{array}$

19.6

101.5

22.5

323

-- 0

23

.. 0

$7 \quad 108.4$

17.2

$\begin{array}{llll}6 & 15 & 102.9 & 19.0\end{array}$

323

-. 0

$32 \quad 143.2$

4. 5

-. 0

$18 \quad 104.3$

19.0

6

8104.1

19.6

(Continued) 
Test

\section{Section}

5

5

5

6

6

6

7
L AC

Aggregate

Subgrade

$\mathrm{H} \quad \mathrm{AC}$

Aggregate

Subgrade

$H \& L \quad A C$

Aggregate

Subgrade

$\mathrm{H} \quad \mathrm{AC}$

Aggregate

Subgrade

L $\quad \mathrm{AC}$

Aggregate

Subgrade

H\&L $\quad$ AC

Subgrade

\section{Thickness, in.}

Design Actual

2.7

5.8

- 0

$-\cdot$

$\begin{array}{ll}6 & 14\end{array}$

$3.5 \quad 2,076$

4.5

-. 0

33

-.

2. 31,414

6.0

-. 0

20

142.6

4.9

-.

$$
\text { -. } 0
$$

6

2.3

5.5

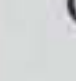

-.

-

-.

$0 \quad 24$

137.4

3.4

016

6

$2.5 \quad 1,104$

6.5

-. 0

-.

$0 \quad 52$

0

6

$2.5 \quad 2,076$

7.0

-. 046

$-\cdot$

0

6

8

5.2

$\begin{array}{lll}0 & 22 & 109.1 \\ 6 & 19 & 106.3\end{array}$

17.6

(Continued)
In-

$\begin{array}{cc}\text { Water } & \text { Place } \\ \text { Content } & \text { Density }\end{array}$

pcf

3.4

18.5

16.5

4.1

19.4

20.6
21.0

18.1

18.3

4.6

17.8

19.4

4.7

19.1

19.9

$\begin{array}{llllll}\cdots & \ldots & 0 & 22 & 109.1 & 15.8 \\ & & 6 & 19 & 106.3 & 17.6\end{array}$

(Sheet 2 of 3 ) 
Test Sectio

8

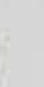

Lane Material H\&L $\quad A C$

\section{Aggregate}

Subgrade

9

$H \& L \quad A C$

Aggregate

Subgrade

10

H\&L AC

Aggregate

Subgrade

11

12

H\&L AC

Subgrade

H\&L AC

Subgrade

6

5.7

-.

4.3

3.6

- -

4.7

5.5

$$
\text { - }
$$

$\begin{array}{cc}4 & 4.3 \\ 4 & 3.6 \\ - & --\end{array}$

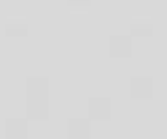

4.7

-.

13

$H \& L$

Subgrade

3.0

3

-.

14 H\&L Aggregate
Subgrade

15

H\&L Aggregate

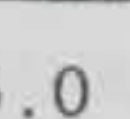

5.8

7.5 Subgrade

Water

In-

Place

Depth CBR Content Density pcf

3

0

$\begin{array}{ll}34 & 130.7\end{array}$

2.3

$$
\begin{array}{lll}
6 & 10 & 107.8
\end{array}
$$

16.2

17.4

5

$\begin{array}{rr}0 & - \\ \cdots & 0\end{array}$

$44 \quad 130.2$

2.4

- 0

$19 \quad 108.0$

16.3

6

$17 \quad 103.1$

16.8

$$
0 \quad-
$$$$
\text { - } 0
$$

$\begin{array}{ll}39 & 129.6\end{array}$

2. 3

$\begin{array}{llll}- & 0 & 20 & 105.9\end{array}$

15.4

6

$\begin{array}{ll}21 & 103.7\end{array}$

18.4

$-$

$\begin{array}{lll}0 & 16 & 104.3\end{array}$

16.3

6

$15 \quad 100.2$

19.0

$16 \quad 100.3$

17.8

$27 \quad 100.0$

17.2

$\begin{array}{rrrr}6 & 27 & 100.0 & 17.2 \\ 0 & 35 & 133.4 & 2.8\end{array}$

$15 \quad 103.9$

18.9

$31 \quad 104.4$

17.4

$\begin{array}{rrrr}6 & 31 & 104.4 & 17.4 \\ 0 & 32 & 13\lrcorner .0 & 2.8\end{array}$

$12 \quad 103.0$

20.2

12100.9

17.8

$\begin{array}{llll}6 & 12 & 100.9 & 17.8\end{array}$

$\begin{array}{ll}32 & 129.0\end{array}$

3.3

$17 \quad 107.8$

18.1

$22 \quad 104.7$

18.3 
Table 2

Test Truck Characteristics

\begin{tabular}{|c|c|c|c|}
\hline \multirow[b]{2}{*}{ Axle } & \multicolumn{3}{|c|}{ Weight, 1b } \\
\hline & Left & Right & Total \\
\hline & High Pres & & \\
\hline Steering & 4,920 & 4,670 & 9,590 \\
\hline Front Drive & 8,625 & 8,180 & 16,805 \\
\hline Rear Drive & 8,230 & 8,200 & 16,430 \\
\hline Front Trailer & 7,835 & 8,520 & 16,355 \\
\hline Rear Trailer & 8,415 & 9,005 & 17,420 \\
\hline Gross Vehicle Weight & & & 76,600 \\
\hline & Low Press & & \\
\hline Steering & 4,880 & 4,650 & 9,530 \\
\hline Front Drive & 8,635 & 8,675 & 17,310 \\
\hline Rear Drive & 8,450 & 8,565 & 17,015 \\
\hline Front Trailer & 8,265 & 8,115 & 16,380 \\
\hline Rear Trailer & 8,655 & 8,500 & 17,155 \\
\hline Gross Vehicle Weight & & & 77,390 \\
\hline
\end{tabular}

Table 3

Summary of Test Traffic

\begin{tabular}{|c|c|c|c|c|}
\hline Pavement & \multicolumn{2}{|c|}{ High Pressure Lane, Passes } & \multicolumn{2}{|c|}{ Low Pressure Lane, Passes } \\
\hline Type & Loaded & Unloaded & Loaded & Unloaded \\
\hline Asphalt & 6,764 & 1,113 & 8,333 & 1,385 \\
\hline Aggregate & 2,645 & 1,112 & 3,089 & 1,384 \\
\hline
\end{tabular}


Table 4

Summary of Rut Depth Measurements Taken in AC Failures

\begin{tabular}{|c|c|c|c|c|c|}
\hline $\begin{array}{c}\text { Test } \\
\text { Section }\end{array}$ & $\underline{\text { Lane }}$ & $\begin{array}{l}\text { Wheel } \\
\text { Path }\end{array}$ & $\begin{array}{c}\text { Number } \\
\text { of } \\
\text { Passes } \\
\end{array}$ & $\begin{array}{l}\begin{array}{l}\text { Maximum } \\
\text { Rut }\end{array} \\
\text { Depth. in. }\end{array}$ & Remarks \\
\hline 4 & $\mathrm{H}$ & 2 & 158 & 2.3 & Severe cracking. \\
\hline 4 & $\mathrm{H}$ & 2 & 323 & 7.0 & Severe cracking. \\
\hline 6 & $\mathrm{H}$ & 1 & 1,104 & 8.3 & Severe cracking. \\
\hline 5 & $\mathrm{H}$ & 1 & 1,414 & 4.9 & Severe cracking. \\
\hline 6 & $\mathrm{~L}$ & 3 & 2,076 & 4.0 & Severe cracking. \\
\hline 5 & L & 4 & 2,076 & 7.5 & Severe cracking. \\
\hline 5 & $\mathrm{H}$ & 1 & 2,210 & 6.0 & Severe cracking. \\
\hline 10 & $\mathrm{H}$ & 1 & 2,210 & 9.0 & $\begin{array}{l}\text { Severe shoving and } \\
\text { cracking. }\end{array}$ \\
\hline 4 & L & 3 & 3,324 & 3.3 & Severe cracking. \\
\hline 4 & $\mathrm{~L}$ & 4 & 3,845 & 3.8 & Severe cracking. \\
\hline
\end{tabular}


Table 5

Summary of Rut Depth Measurements Taken in Aggregate Failures

\begin{tabular}{|c|c|c|c|c|c|c|}
\hline $\begin{array}{l}\text { Test } \\
\text { Section }\end{array}$ & Lane & $\begin{array}{l}\text { Wheel } \\
\text { Path }\end{array}$ & $\begin{array}{c}\text { Number } \\
\text { of Passes } \\
\text { Loaded/ } \\
\text { (Unloaded) }\end{array}$ & $\begin{array}{c}\text { Maximum } \\
\text { Rut } \\
\text { Depth } \\
\text { in. } \\
\end{array}$ & $\begin{array}{l}\text { Degree } \\
\text { of Wash- } \\
\text { boarding } \\
\end{array}$ & Remarks \\
\hline 1 & $\mathrm{H}$ & 2 & 58 & 4.0 & None & $\begin{array}{l}\text { Failed section overlaid with } 12 \text { in. of } \\
\text { aggregate. }\end{array}$ \\
\hline 2 & $\mathrm{H}$ & 1 & 58 & 4.8 & Low & $\begin{array}{l}\text { Failed section overlaid with } 12 \text { in. of } \\
\text { aggregate. }\end{array}$ \\
\hline 3 & $\mathrm{H}$ & 1 & 58 & 3.5 & None & $\begin{array}{l}\text { Failed section overlaid with } 12 \text { in. of } \\
\text { aggregate. }\end{array}$ \\
\hline 1 & L & 3 & 66 & 5.0 & None & $\begin{array}{l}\text { Failed section overlaid with } 12 \text { in. of } \\
\text { aggregate. }\end{array}$ \\
\hline 2 & L & 4 & 66 & 3.0 & None & $\begin{array}{l}\text { Failed section overlaid with } 12 \text { in. of } \\
\text { aggregate. }\end{array}$ \\
\hline 3 & L & 3 & 66 & 4.5 & None & $\begin{array}{l}\text { Failed section overlaid with } 12 \text { in. of } \\
\text { aggregate. }\end{array}$ \\
\hline 2 & $\mathrm{H}$ & 1 & 60 (112) & 6.9 & Moderate & Failed; section graded. \\
\hline 2 & $\mathrm{H}$ & 1 & $282(259)$ & 5.0 & Severe & Failed; section graded. \\
\hline 2 & $\mathrm{H}$ & 1 & $282(282)$ & 4.5 & Severe & Failed; section graded. \\
\hline 2 & $\mathrm{H}$ & 1 & $282(342)$ & 4.5 & Moderate & Failed; section graded. \\
\hline 2 & $\mathrm{H}$ & 1 & $584(556)$ & 4.0 & Severe & Section graded. \\
\hline 13 & $\mathrm{H}$ & 1 & $883(672)$ & 4.3 & Low & $\begin{array}{l}86 \text { passes in rain; rutting increased } \\
3.1 \text { in.; graded. }\end{array}$ \\
\hline 13 & L & 4 & $1,077(838)$ & 4.8 & Low & $\begin{array}{l}98 \text { passes in rain; rutting increased } \\
3.3 \text { in.; graded. }\end{array}$ \\
\hline 14 & $\mathrm{H}$ & 2 & $883(672)$ & 5.8 & Low & $\begin{array}{l}86 \text { passes in rain; rutting increased } \\
4.0 \text { in.; graded. }\end{array}$ \\
\hline 14 & L & 3 & $1,077(838)$ & 5.0 & Low & $\begin{array}{l}98 \text { passes in rain; rutting increased } \\
\text { 3.2 in.; graded. }\end{array}$ \\
\hline 15 & $\mathrm{H}$ & 1 & $883(672)$ & 4.3 & Low & $\begin{array}{l}86 \text { passes in rain; rutting increased } \\
1.5 \text { in.; graded. }\end{array}$ \\
\hline
\end{tabular}


Table 5 (Concluded)

\begin{tabular}{|c|c|c|c|c|c|c|}
\hline $\begin{array}{l}\text { Test } \\
\text { Section }\end{array}$ & Lane & $\begin{array}{l}\text { Whee1 } \\
\text { Path }\end{array}$ & $\begin{array}{c}\text { Number } \\
\text { of Passes } \\
\text { Loaded/ } \\
\text { (Unloaded) }\end{array}$ & $\begin{array}{l}\text { Maximum } \\
\text { Rut } \\
\text { Depth } \\
\text { in. } \\
\end{array}$ & $\begin{array}{l}\text { Degree } \\
\text { of Wash- } \\
\text { boarding }\end{array}$ & Remarks \\
\hline 15 & $\mathrm{~L}$ & 4 & $1,077(838)$ & 3.5 & Low & $\begin{array}{l}98 \text { passes in rain; rutting increased. } \\
1.2 \text { in.; graded. }\end{array}$ \\
\hline 13 & $\mathrm{H}$ & 2 & $1,331(1,112)$ & 2.3 & Low & Section graded prior to watering. \\
\hline 13 & $\mathrm{~L}$ & 3 & $1,600(1,384)$ & 1.4 & Low & Section graded prior to watering. \\
\hline 14 & $\mathrm{H}$ & 1 & $1,331(1,112)$ & 2.0 & Low & Section graded prior to watering. \\
\hline 14 & $\mathrm{~L}$ & 3 & $1,600(1,384)$ & 1.8 & Low & Section graded prior to watering. \\
\hline 15 & $\mathrm{H}$ & 2 & $1,331(1,112)$ & 1.6 & Low & Section graded prior to watering. \\
\hline 15 & $\mathrm{~L}$ & 4 & $1,600(1,384)$ & 2.5 & Low & Section graded prior to watering. \\
\hline 14 & $\mathrm{H}$ & 2 & $2,015(1,112)$ & 4.9 & Severe & Failed; section graded. \\
\hline 15 & $\mathrm{H}$ & 2 & $2,103(1,112)$ & 4.0 & Severe & Failed; section graded. \\
\hline 15 & $\mathrm{H}$ & 1 & $2,321(1,112)$ & $>4.0$ & Moderate & Failed. \\
\hline 15 & $\mathrm{H}$ & 1 & $2,544(1,112)$ & 4.9 & Moderate & Failed. \\
\hline
\end{tabular}






Figure 1. Plan view of test road 


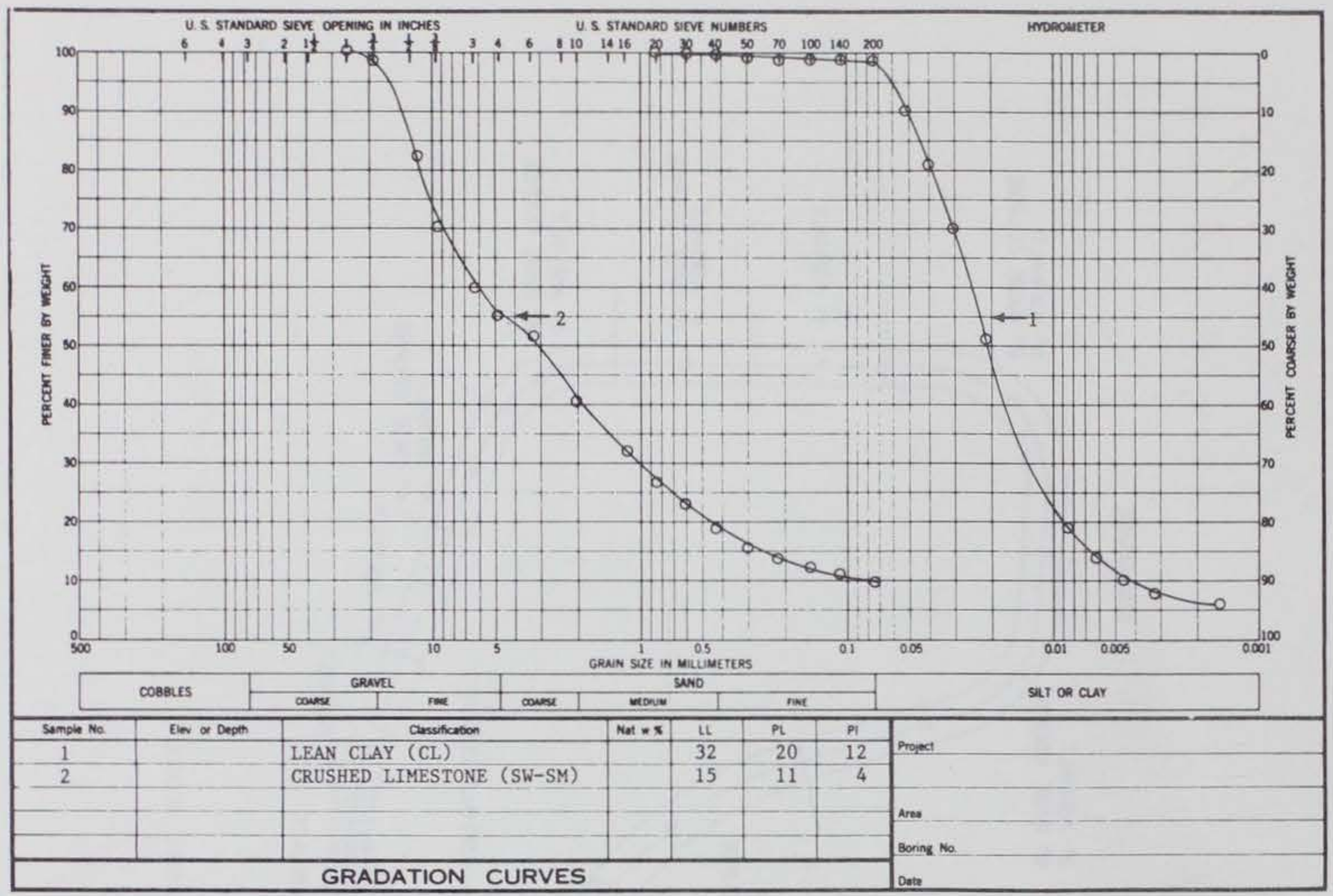

ENG , MORM 2087

Figure 2. Classification data for subgrade and base materials

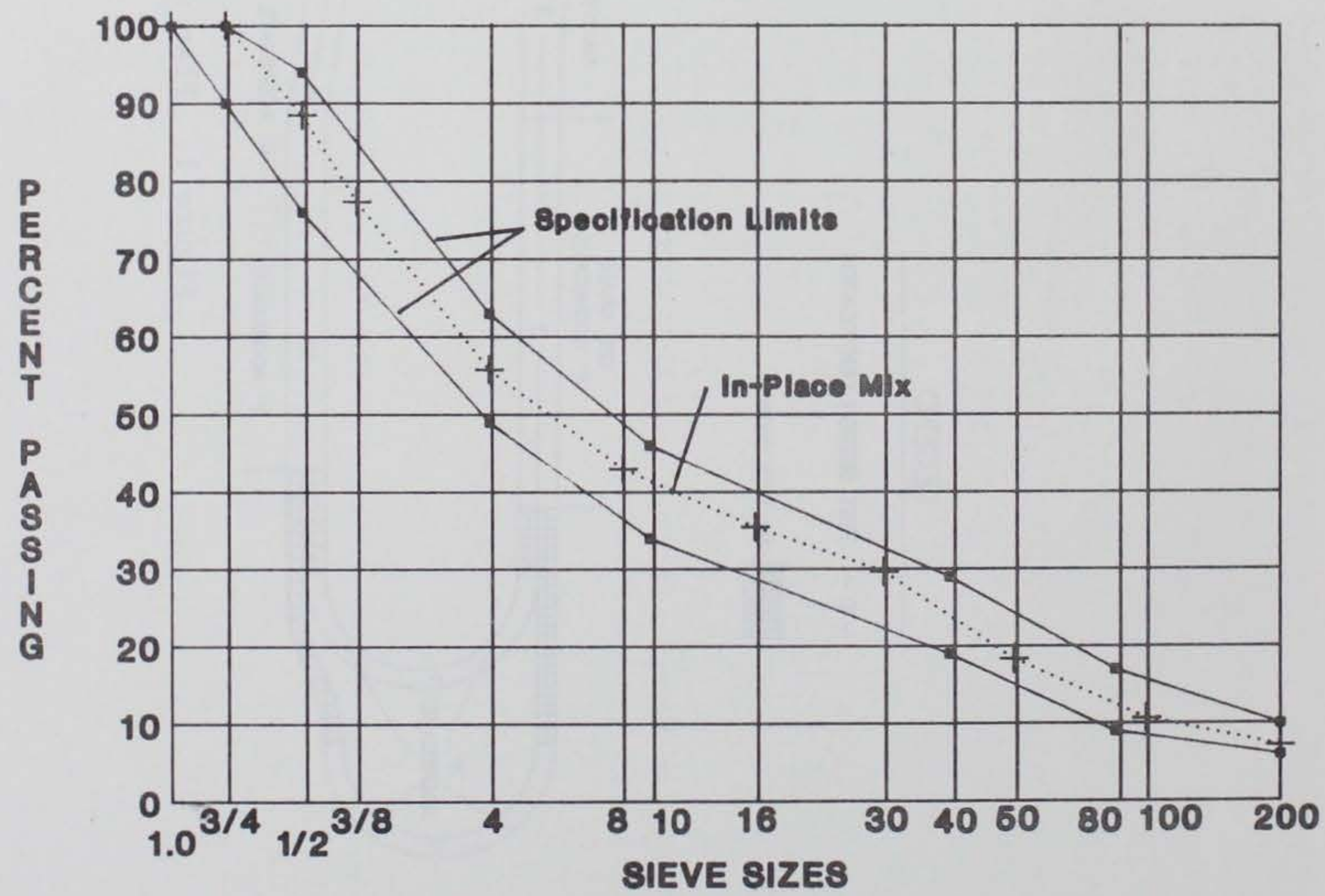

Figure 3. Combined gradation curve and gradation specification limits for asphalt concrete 


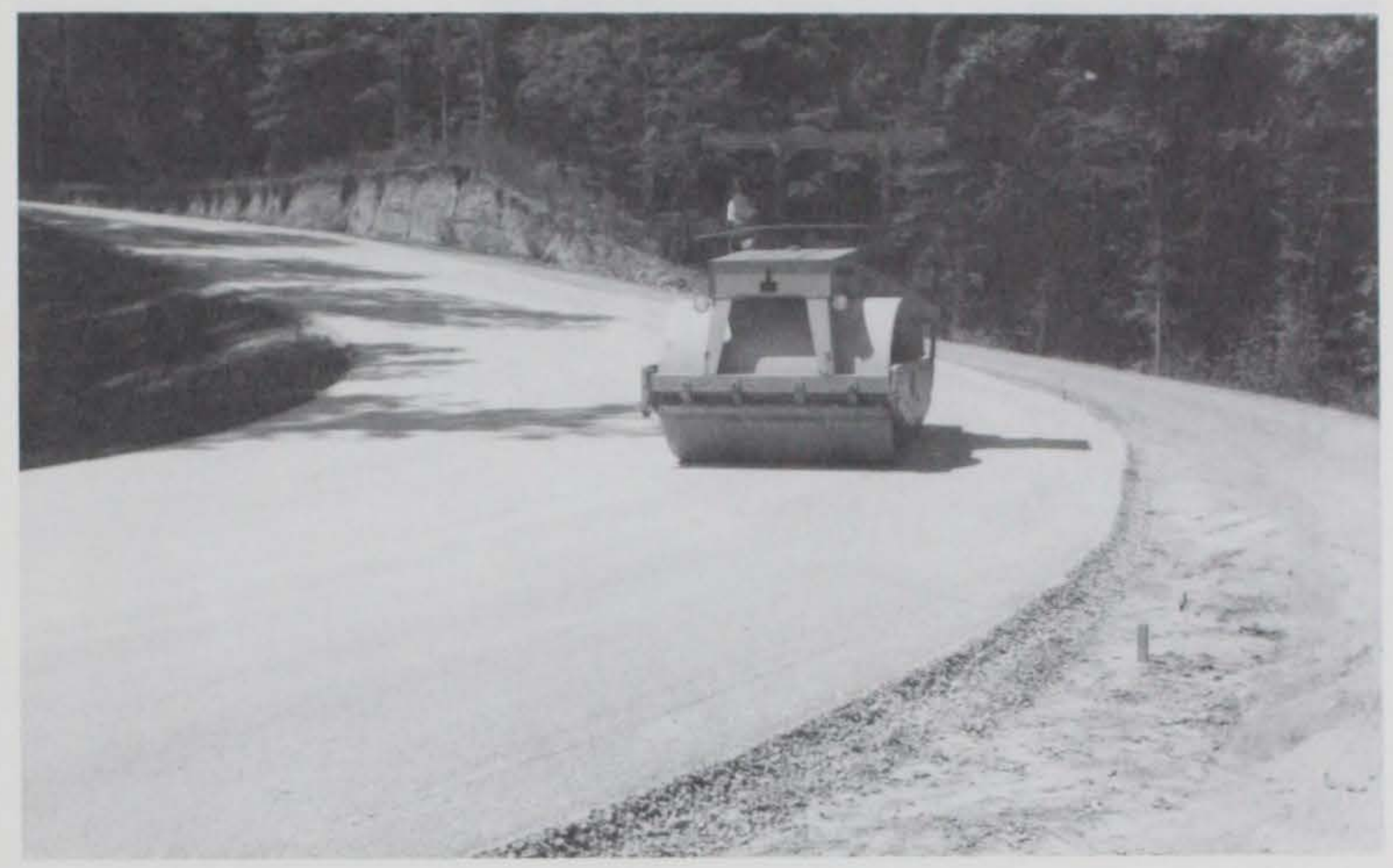

Figure 4. Compaction of the aggregate base material

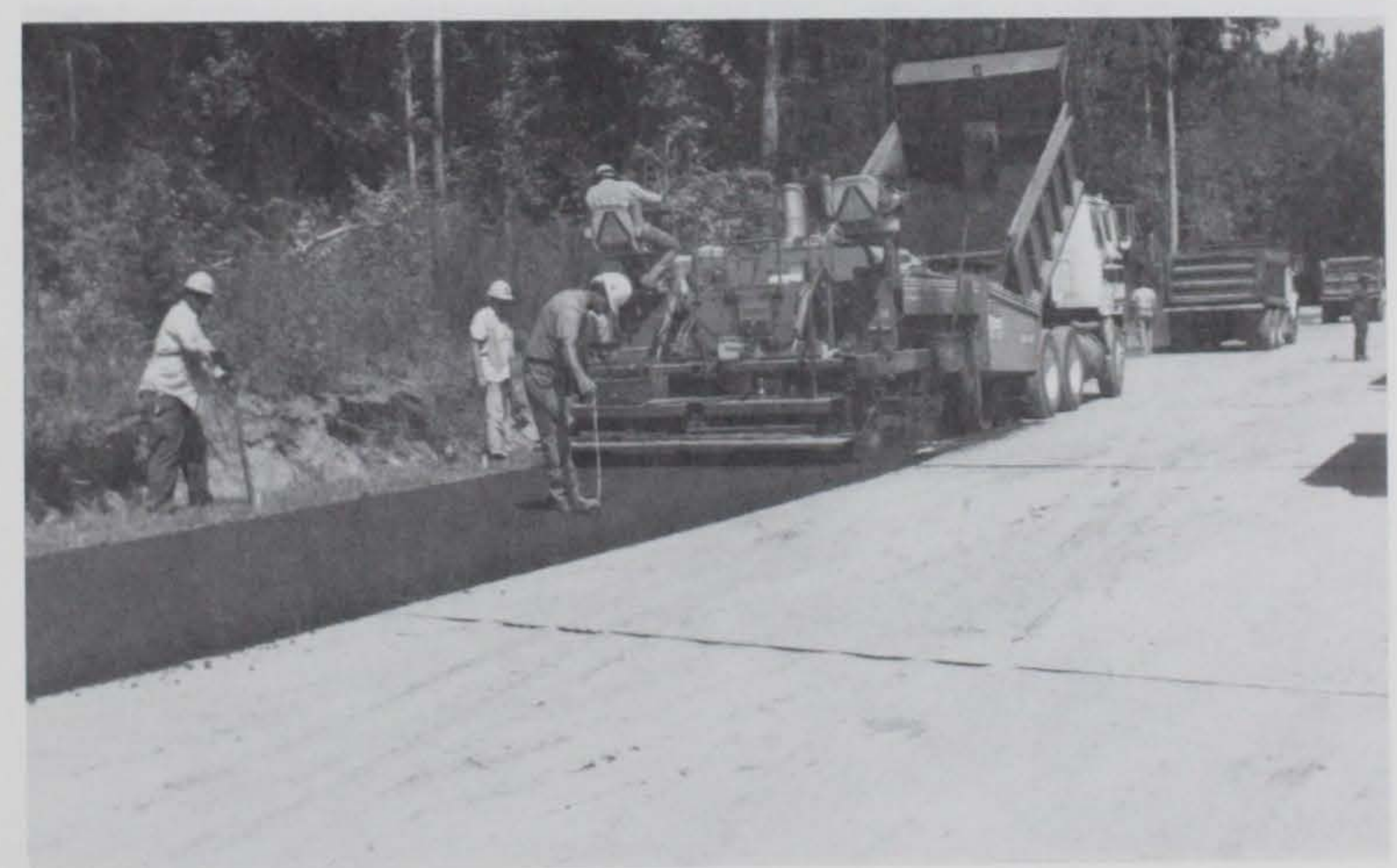

Figure 5. Placement of the asphalt concrete 


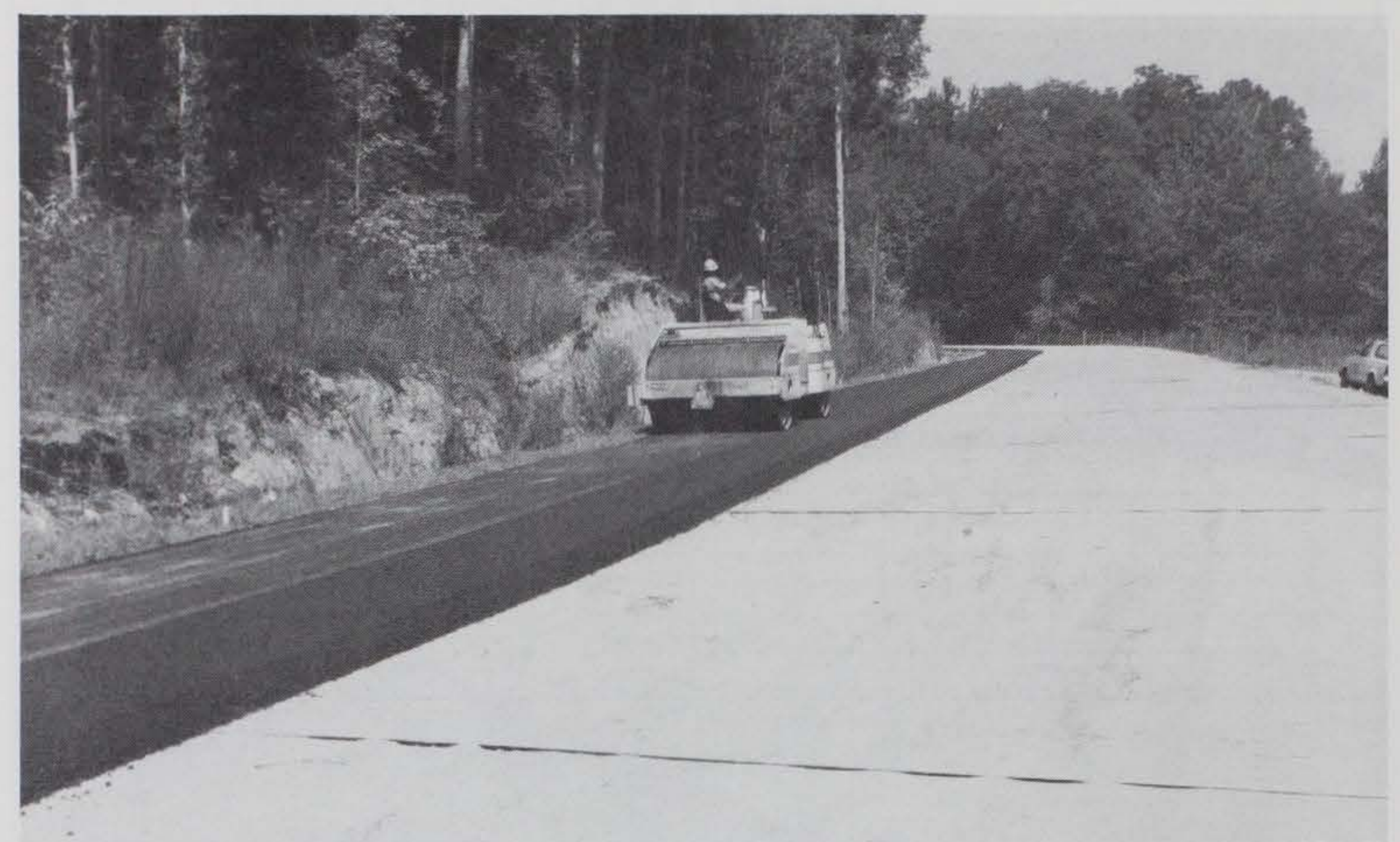

Figure 6. Breakdown rolling of the hot asphalt mix

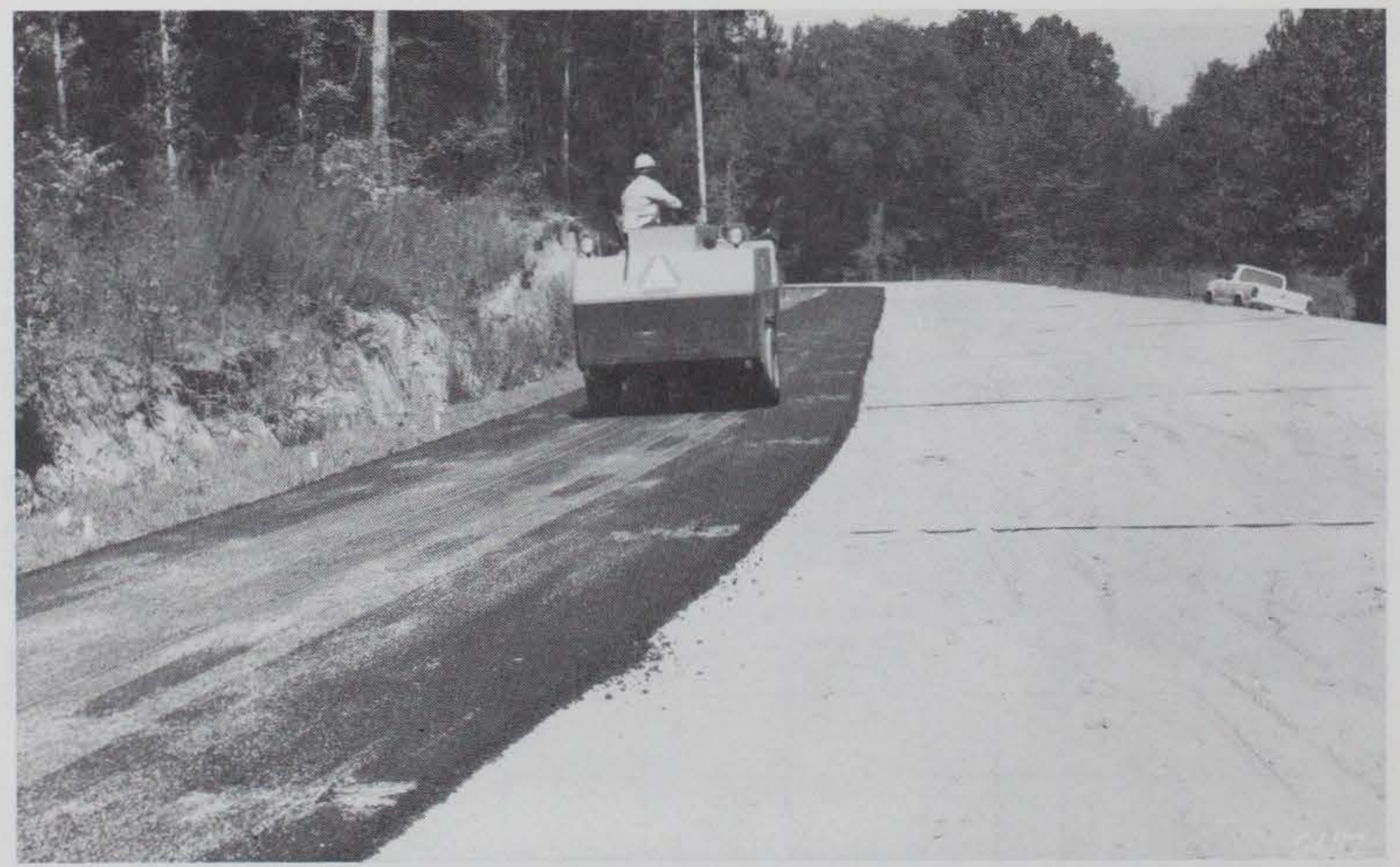

Figure 7. Compaction of the asphalt pavement 




Figure 8. Test vehicles

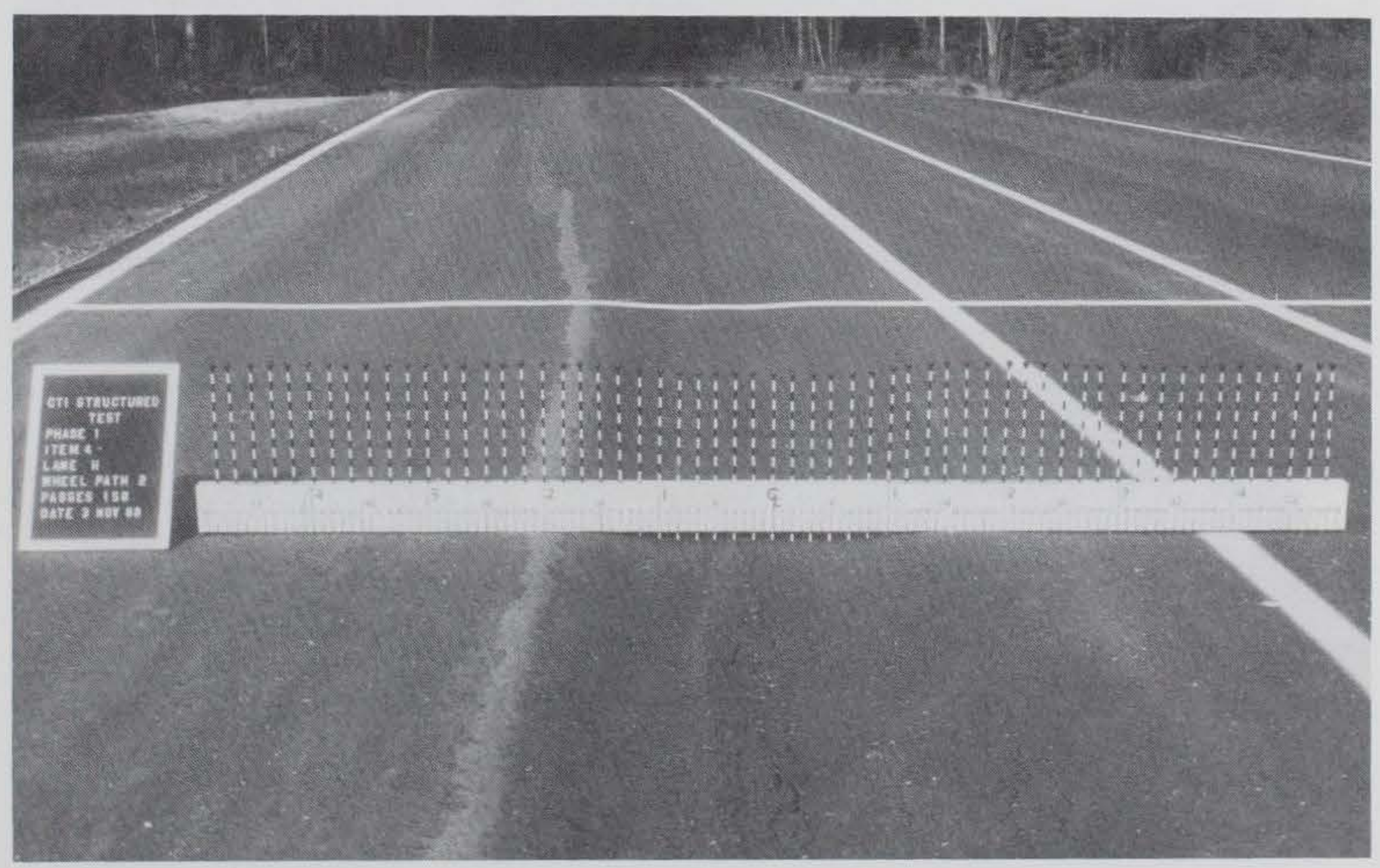

Figure 9. High-tire-pressure lane, section 4, general view of initial failure, 158 passes 




Figure 10. High-tire-pressure lane, section 4, second failure, 323 passes



Figure 11. High-tire-pressure lane, section 4, test trench after 323 passes 


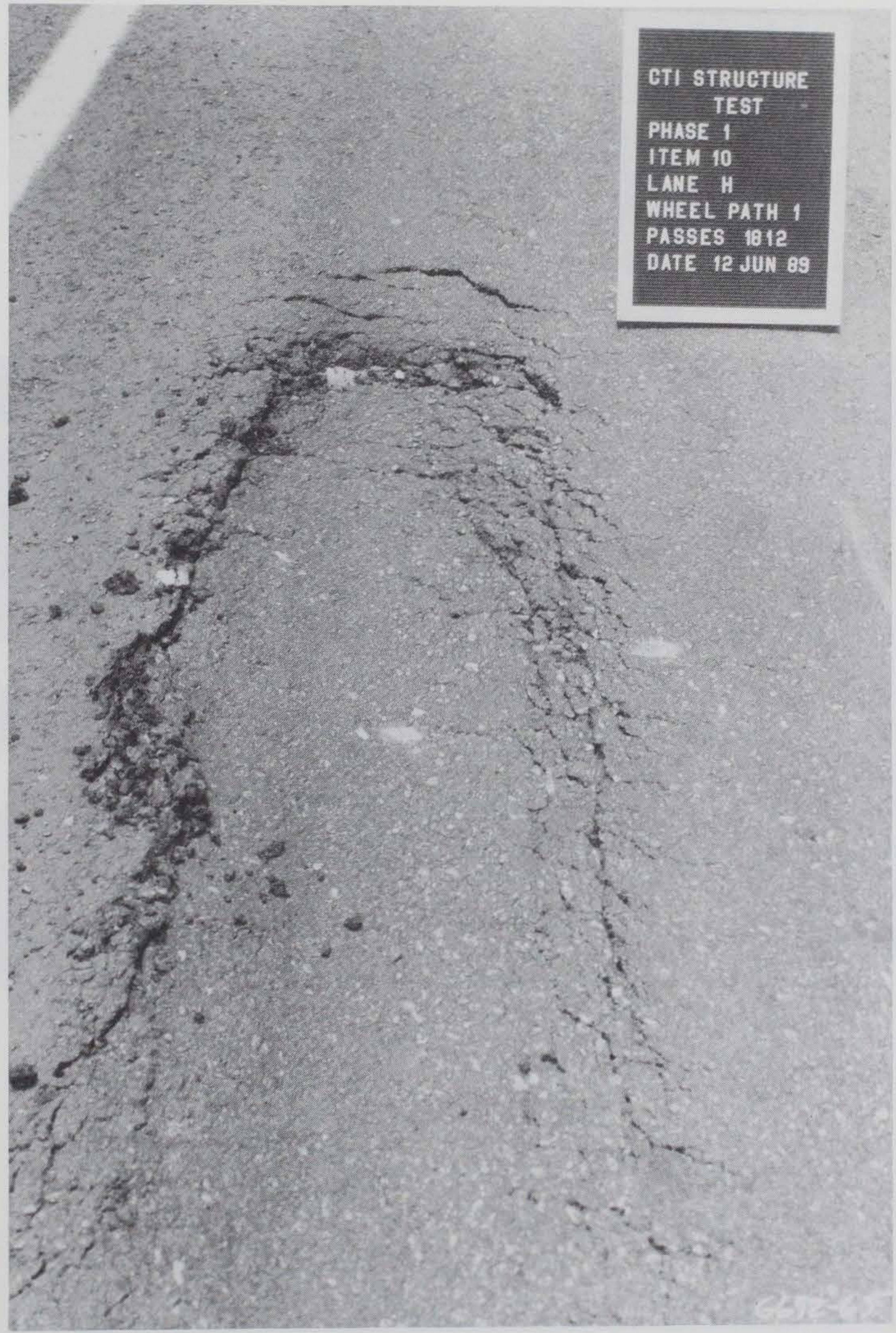

Figure 12. High-tire-pressure lane, section 10 , shoving after 1,812 passes 


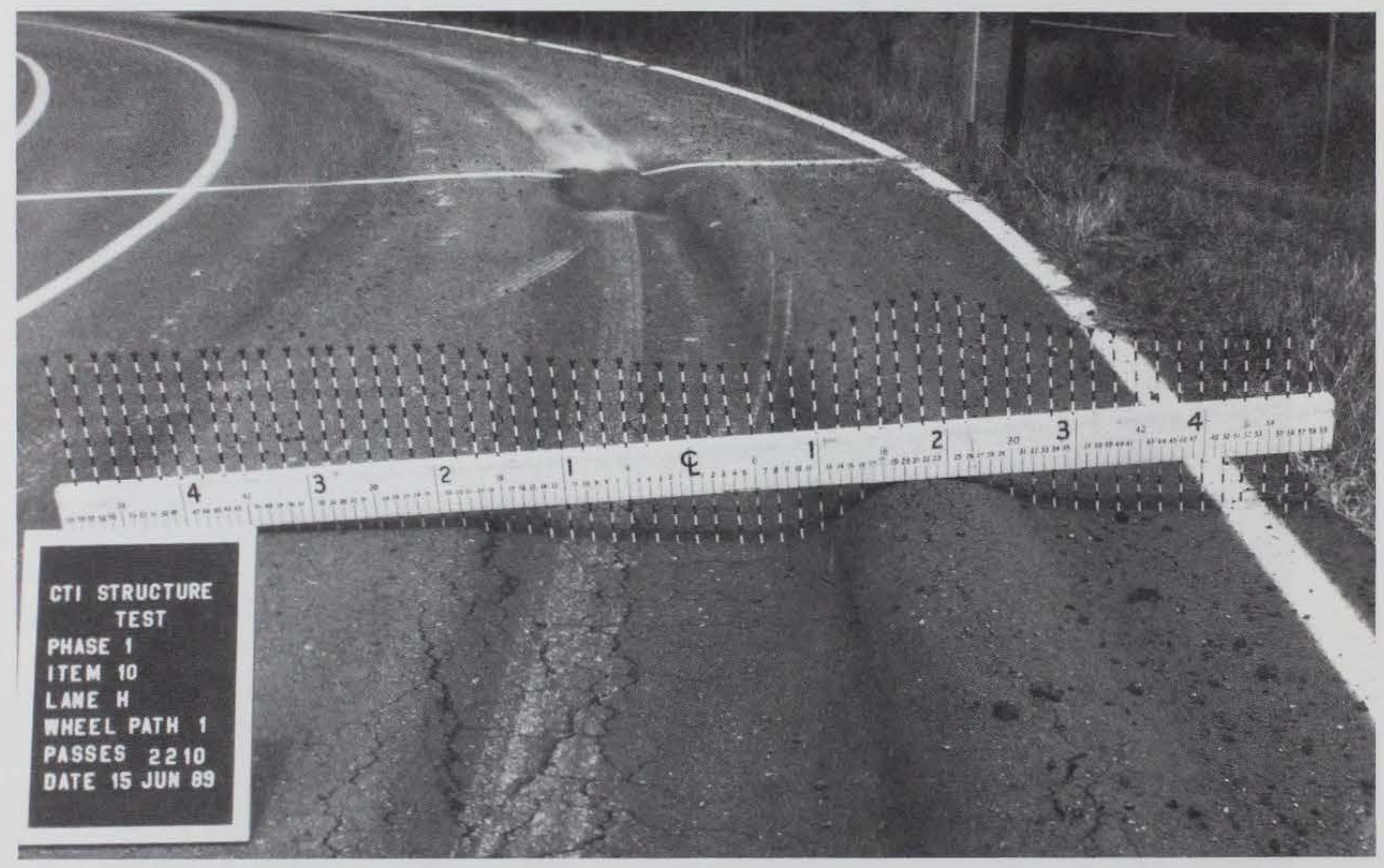

Figure 13. High-tire-pressure lane, section 10, failure after 2,210 passes 


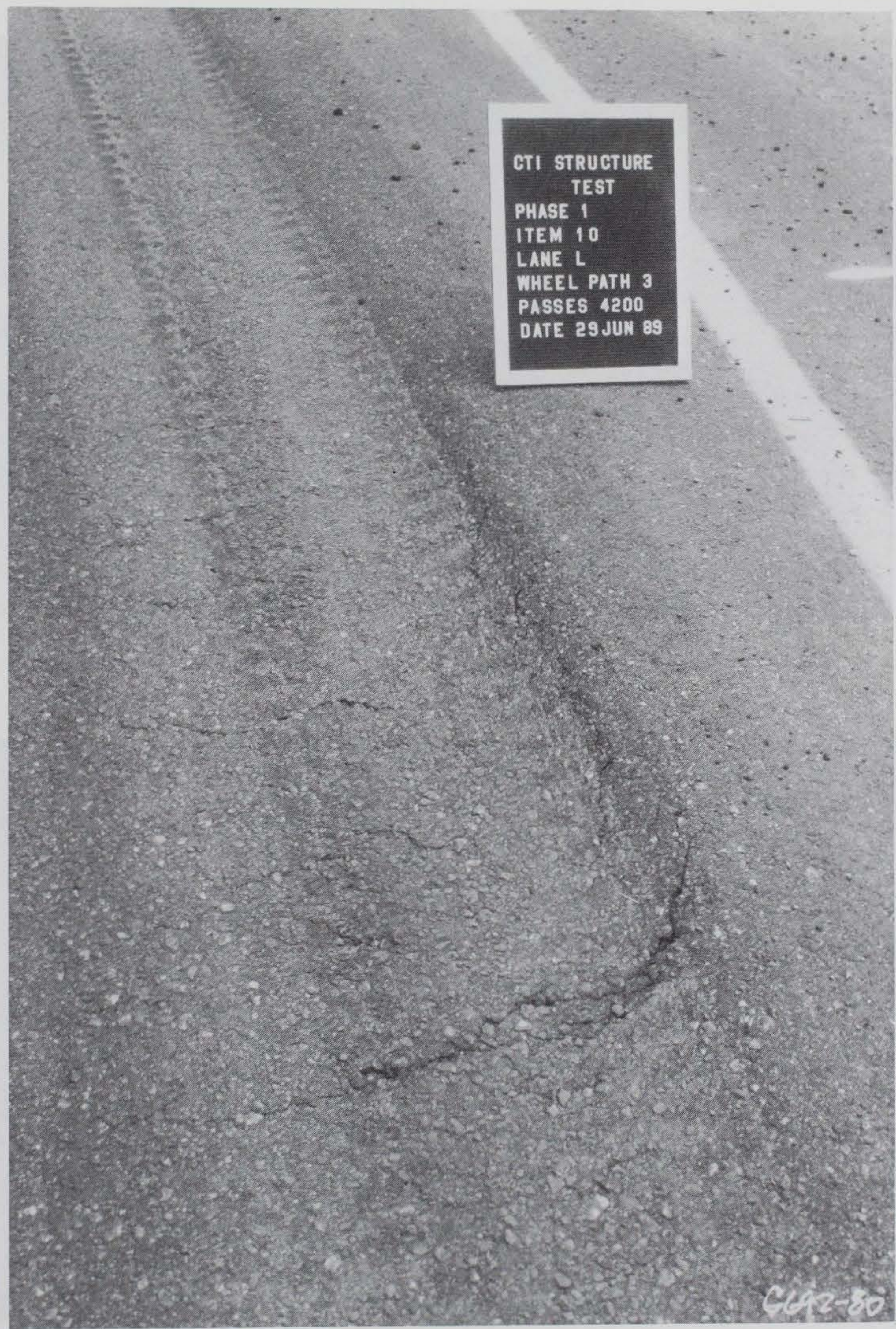

Figure 14. Low-tire-pressure lane, section 10, low severity shoving after 4,200 passes 


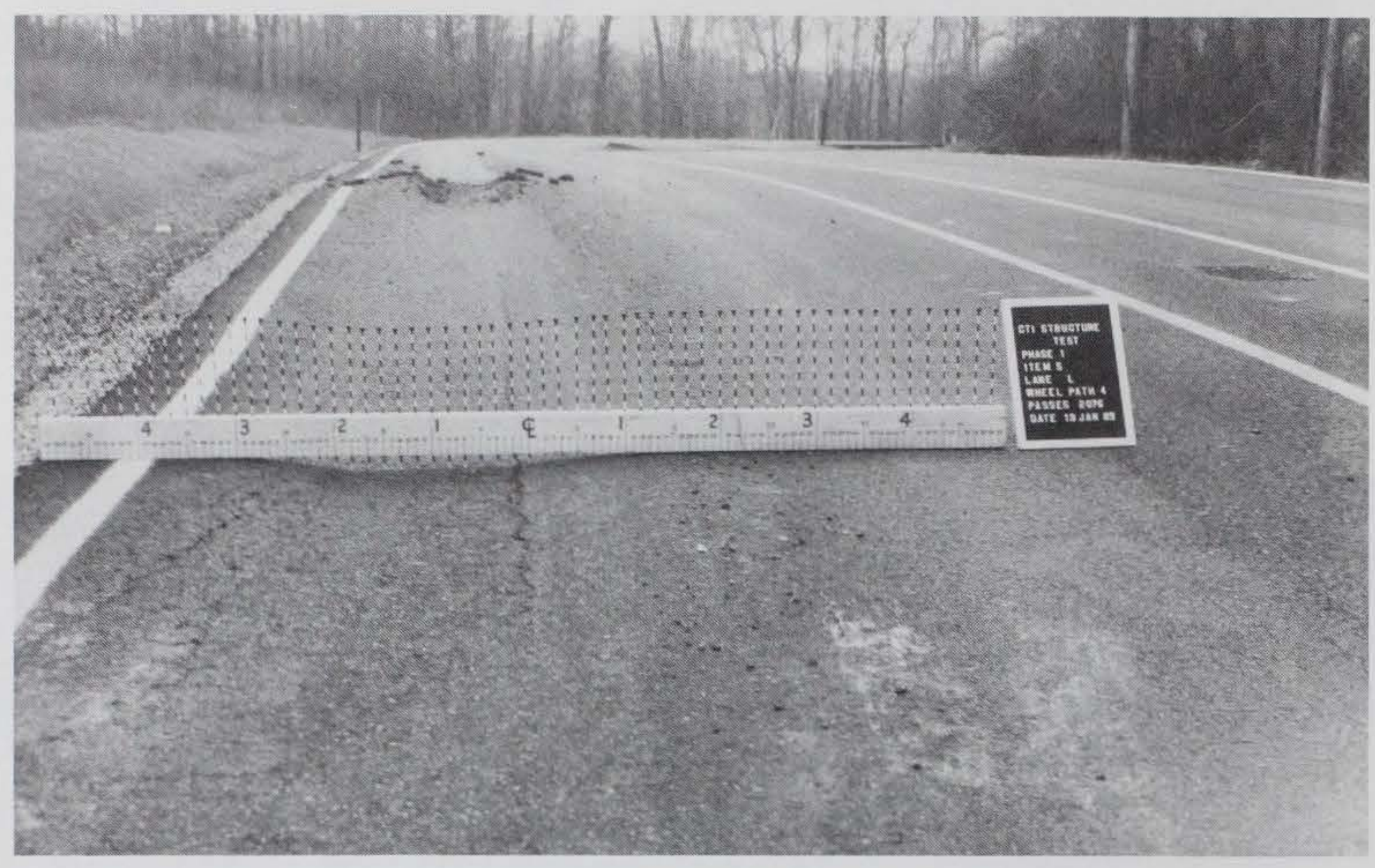

Figure 15. Low-tire-pressure lane, section 5, failure after 2,076 passes

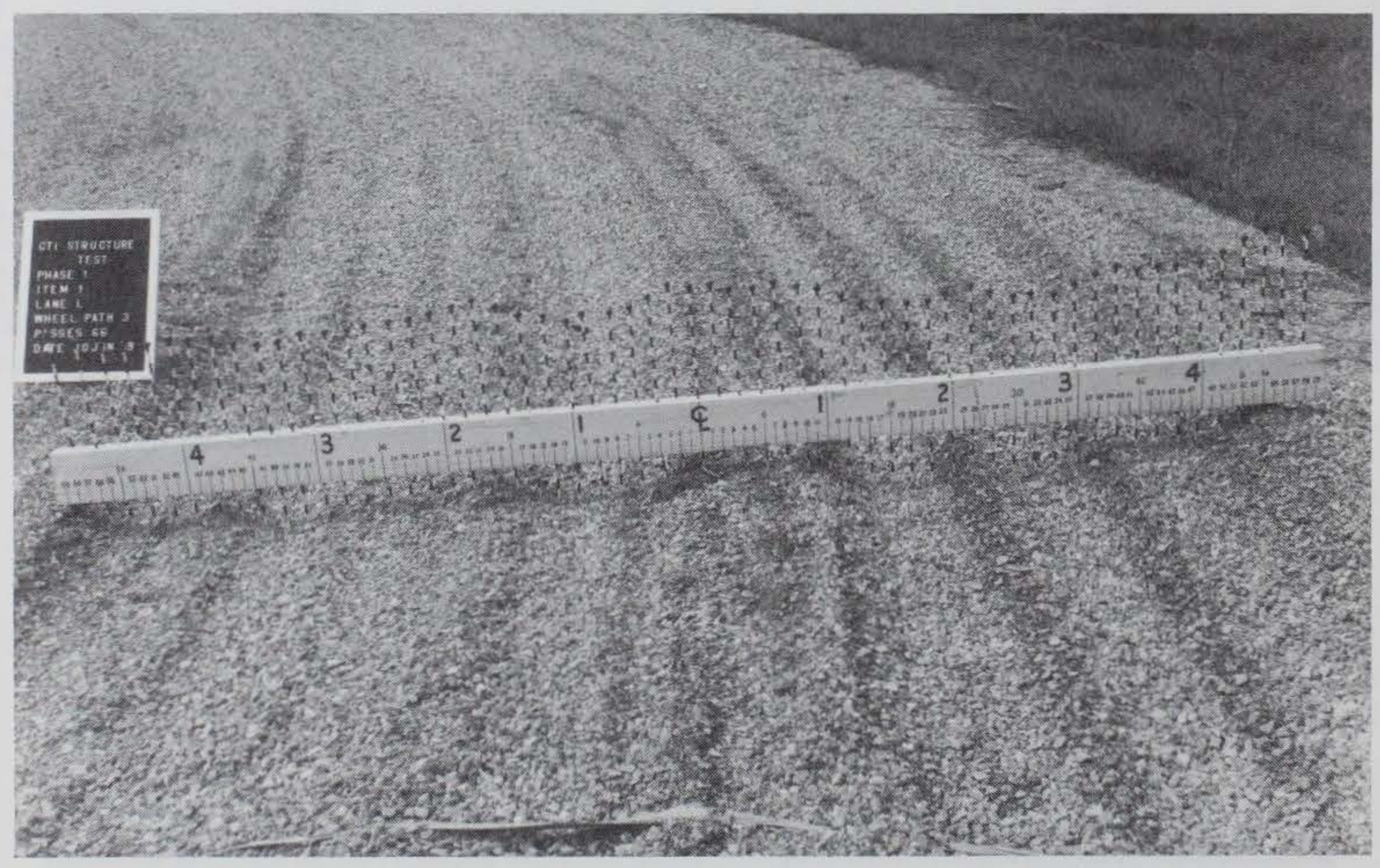

Figure 16. Low-tire-pressure lane, section 1, failure after 66 passes 




Figure 17. High-tire-pressure lane, section 1, failure after 58 passes

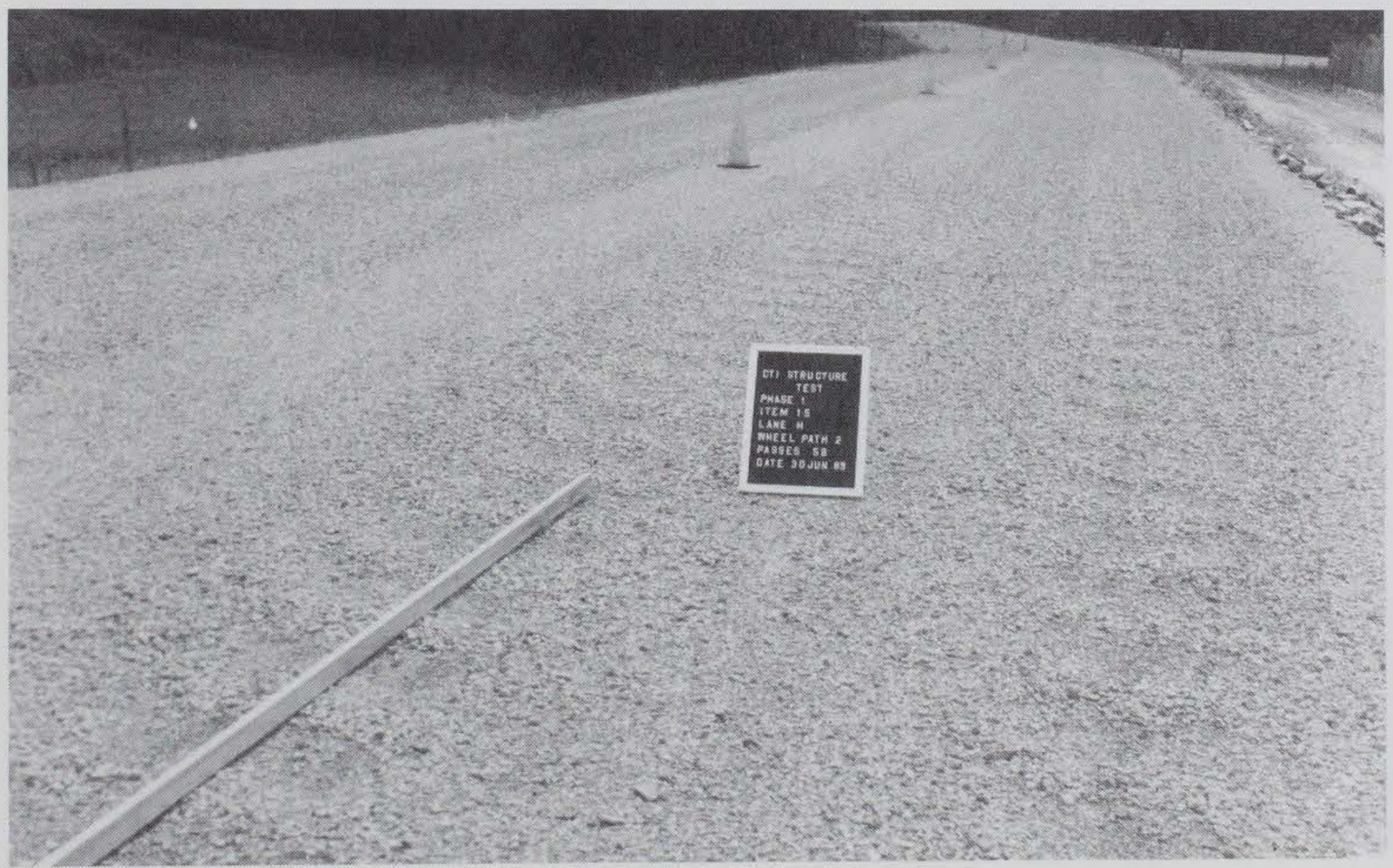

Figure 18. High-tire-pressure lane, section 15, low severity washboarding after 58 passes 


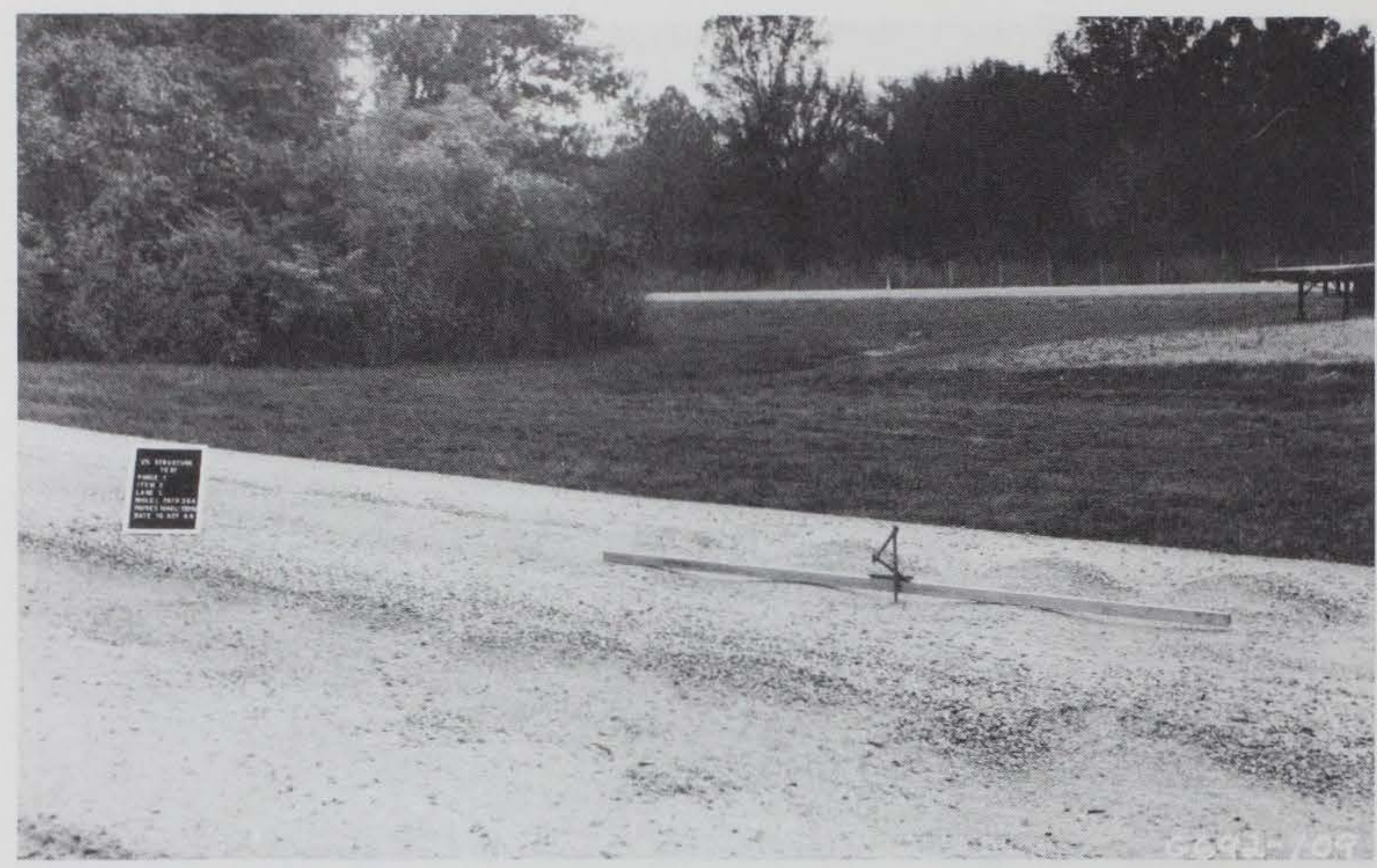

Figure 19. Low-tire-pressure lane, section 2, long intervals between corrugations

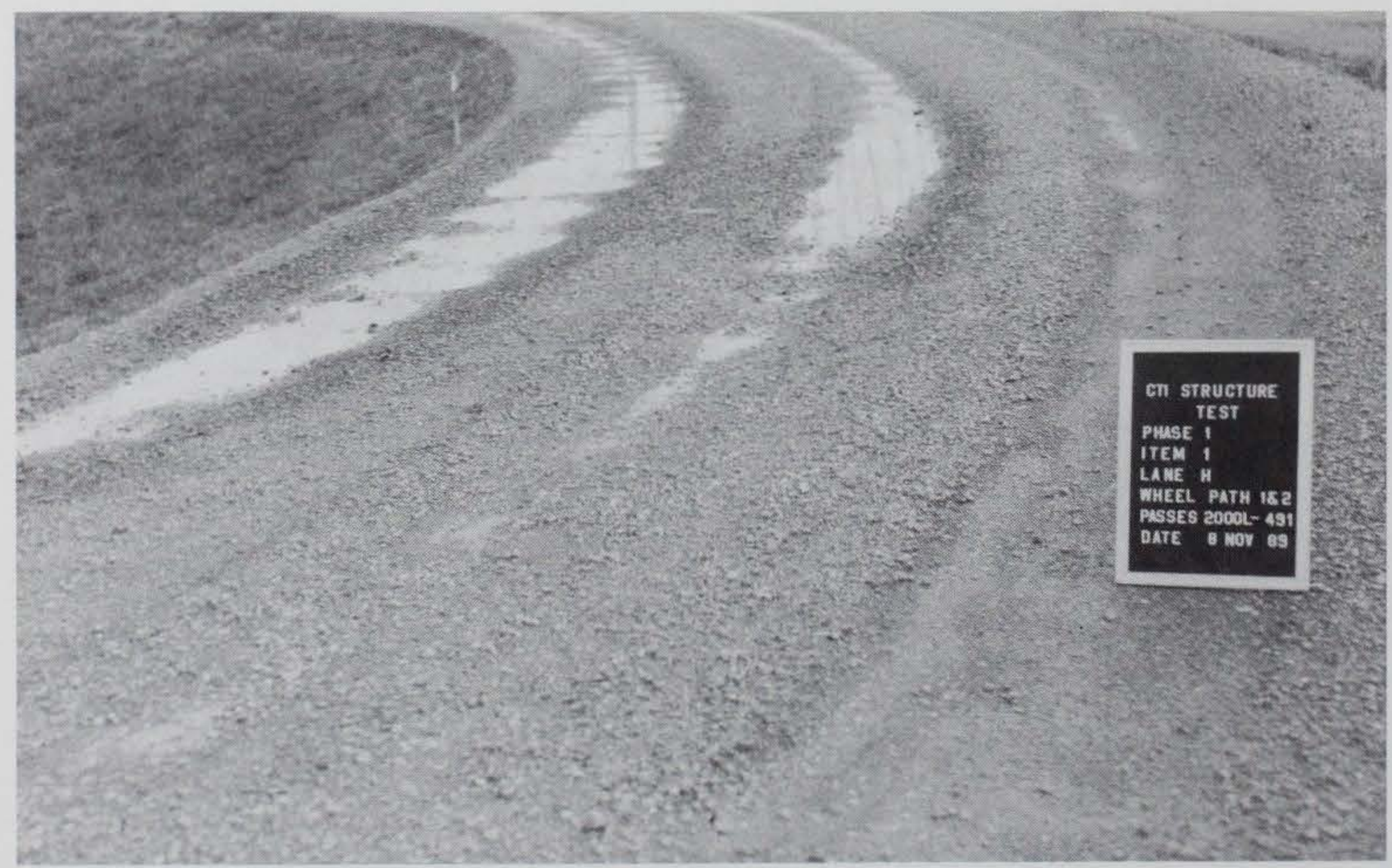

Figure 20. High-tire-pressure lane, section 2, low severity rutting and corrugation 


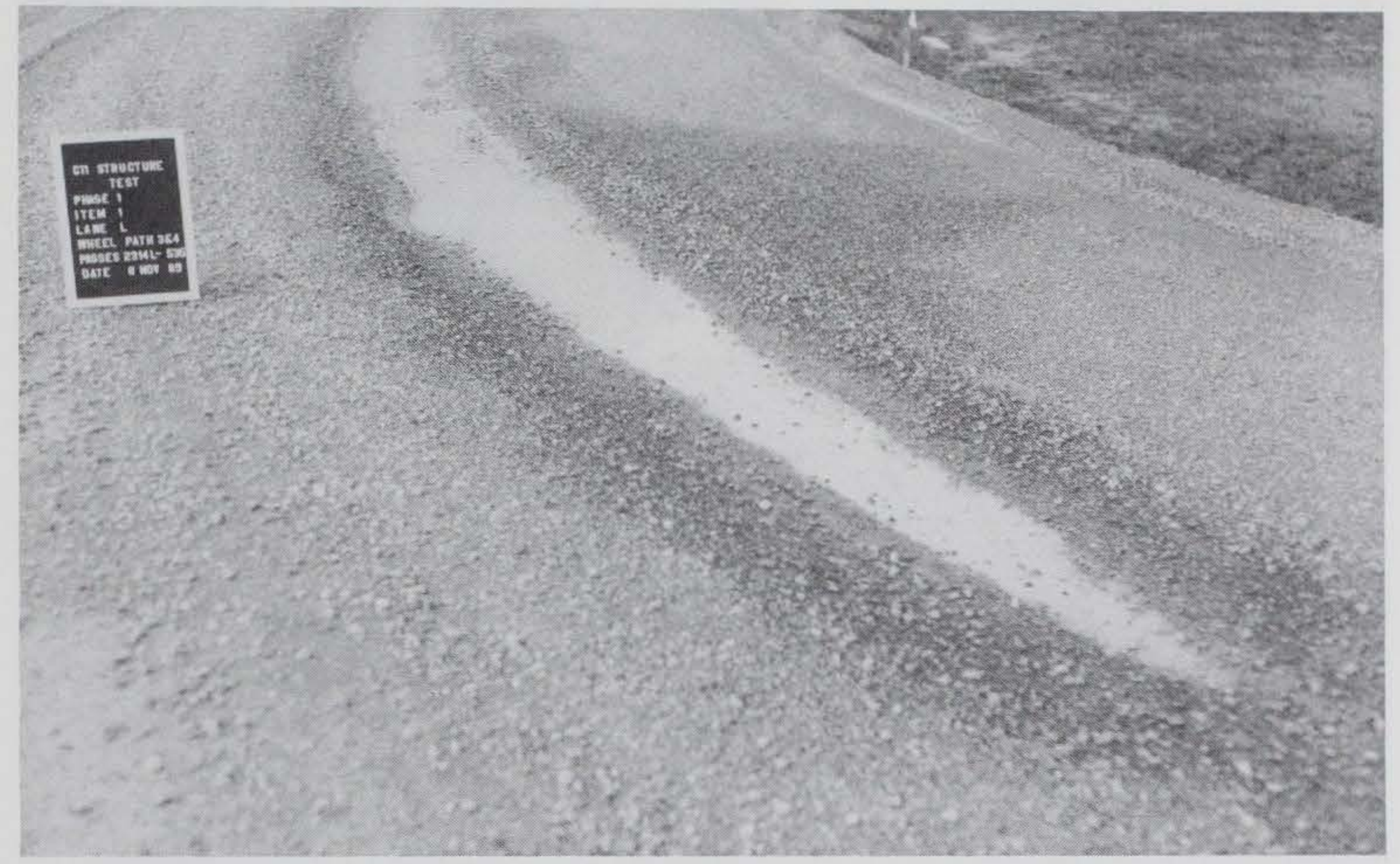

Figure 21. Low-tire-pressure lane, section 1 , low-severity rutting

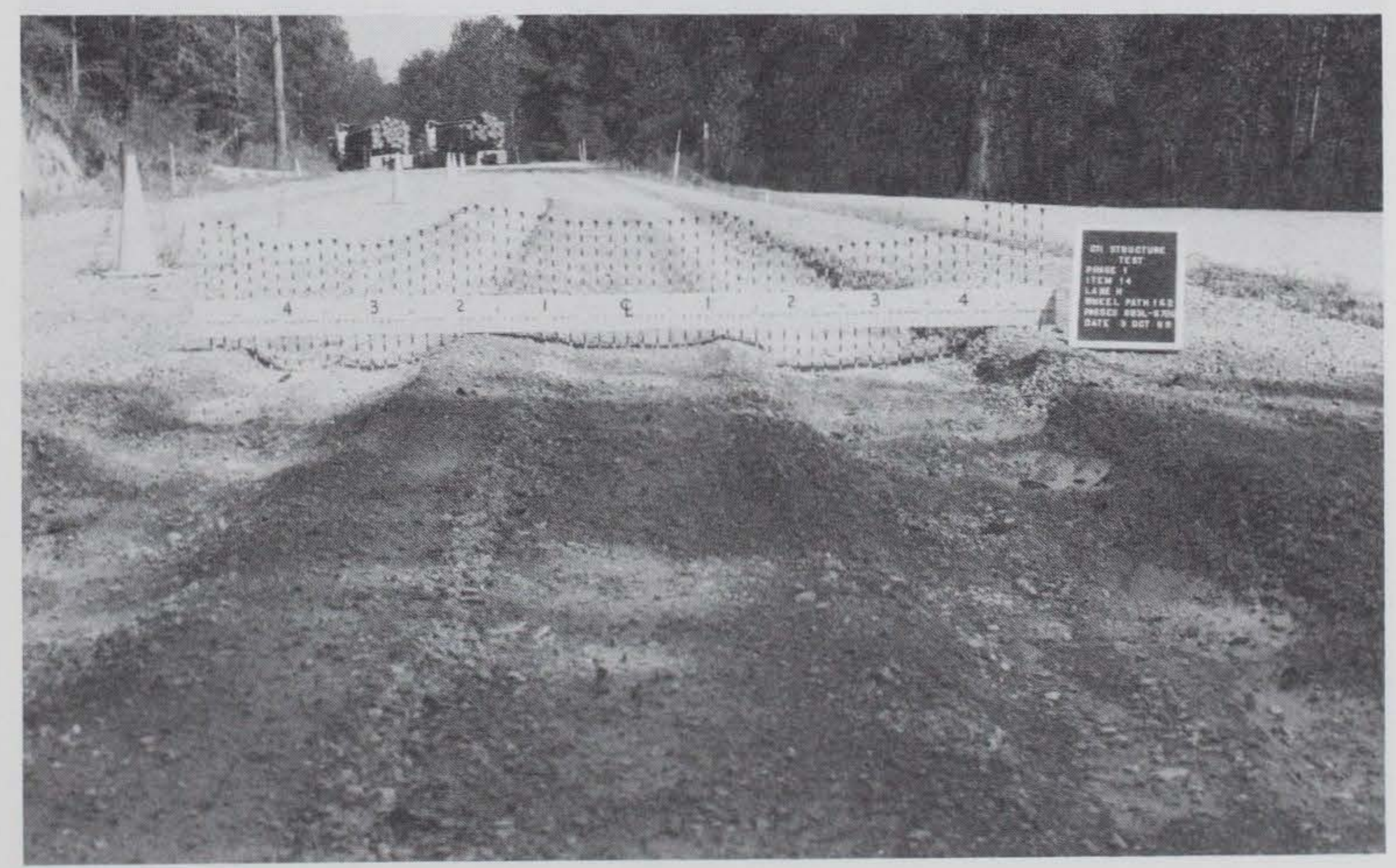

Figure 22. High-tire pressure lane, section 14, highseverity rutting after 90 passes in the rain 


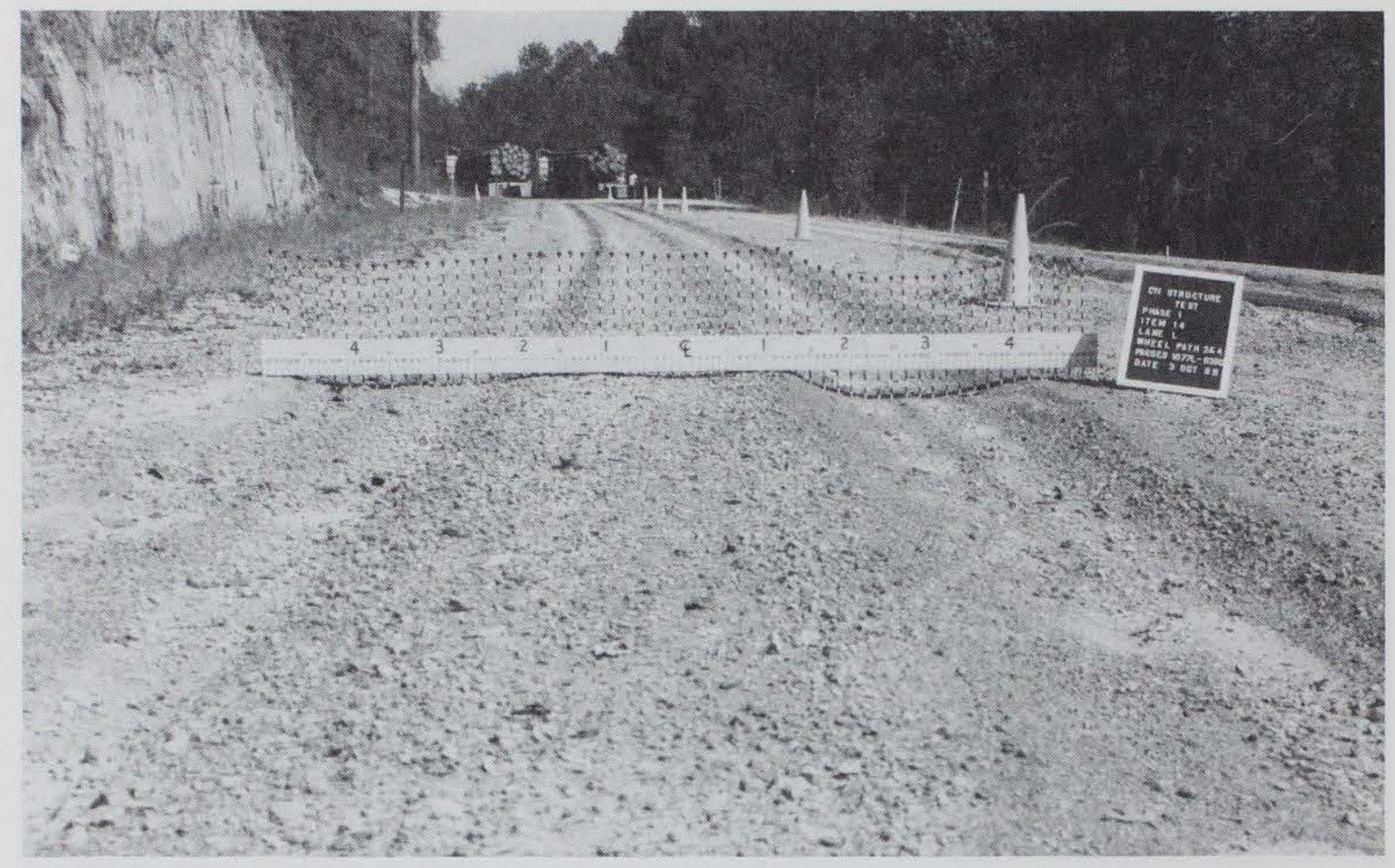

Figure 23. Low-tire-pressure lane, section 14, highseverity rutting after 90 passes in the rain

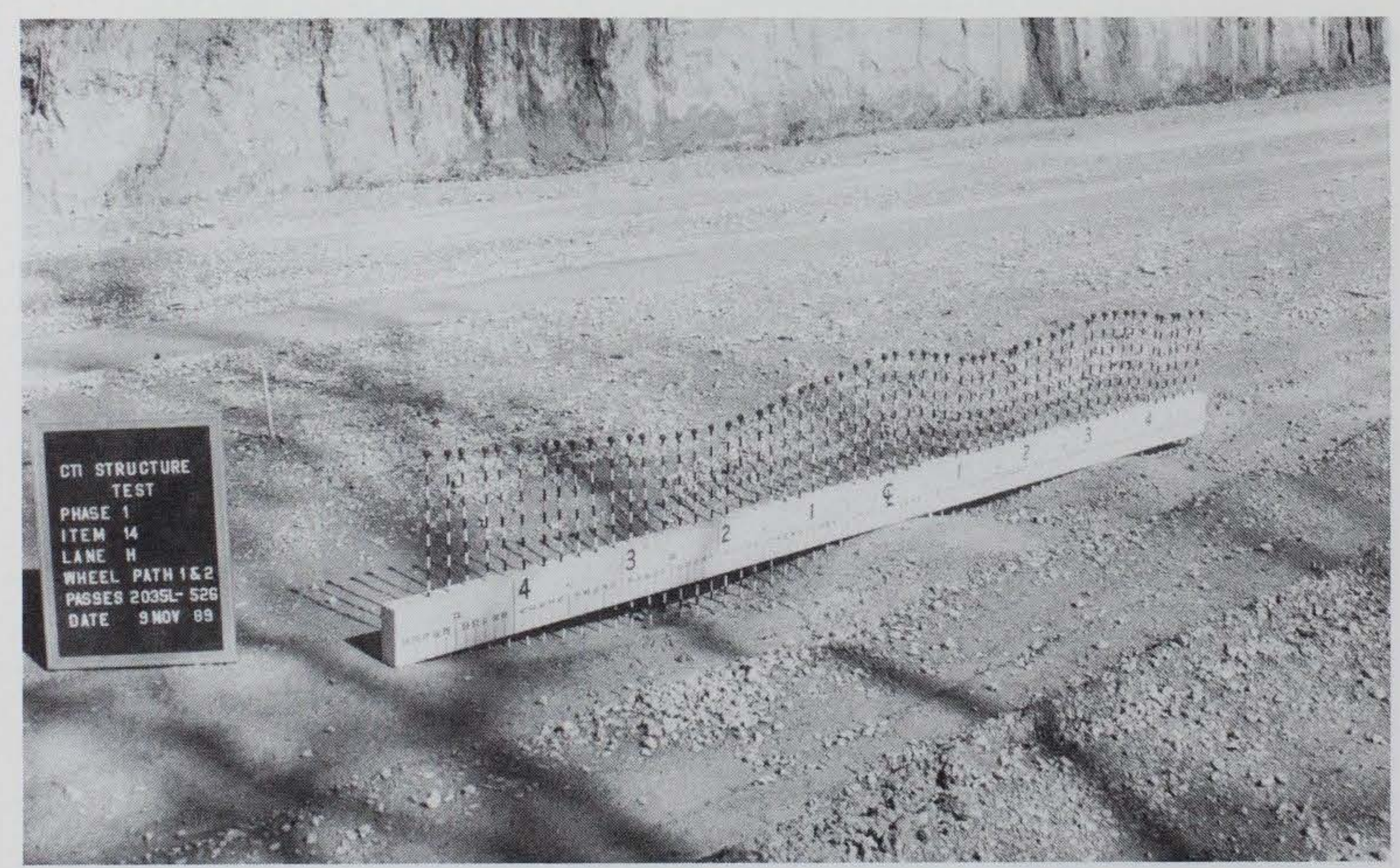

Figure 24. High-tire-pressure lane, section 14, highseverity washboarding 


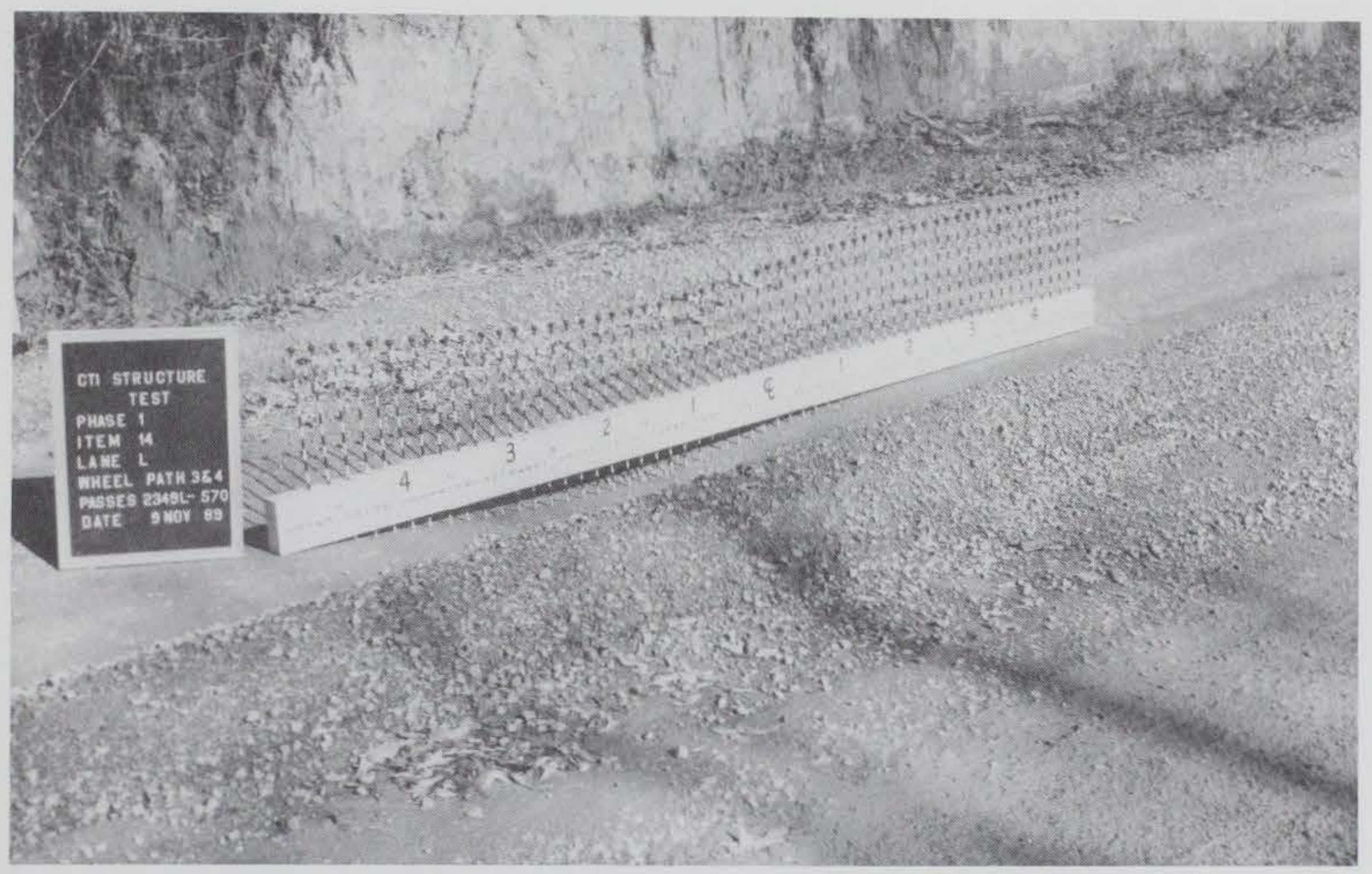

Figure 25. Low-tire-pressure lane, section 14 , low-severity depression 